\title{
BOCCACCIO'S HELLENISM AND THE FOUNDATIONS OF MODERNITY
}

\author{
David Lummus
}

The first sentence of the final book of Giovanni Boccaccio's Genealogie Deorum Gentilium defines the way we should conceive of the importance of the previous thirteen books on Greco-Roman myth and the defense of poetry in Book Fourteen:

Fundavi, serenissime rex, quibus potui armamentis hinc inde naviculam, ne estu procellosi maris aut ventorum adverso impetu pelleretur in litus, et illisa ruptis compagibus solveretur.

[I have now secured (fundavi) my little bark (navicula), O most clement King, by such means as I could, for fear she should be driven ashore by the wash of a stormy sea or the counterforce of the wind, with joints sprung and timbers crushed. $]^{1}$

The first word of this sentence, fundavi, from fundare, "to found, establish, or secure," expresses precisely what Boccaccio has done in his treatise and what he completes in the fifteenth book: he has founded and secured a fully articulated cultural project. The imagery of this final proem is the same as that of the earlier books: his study is presented metaphorically as a navicula, or "bark," and Boccaccio himself as a traveler, as he crosses the sea of time and space that separates him from antiquity. Following the letter of his metaphor, Boccaccio has just anchored his ship, securing it against the waves and winds of fortune and envy. Looking more closely, though, it is clear that he thinks to have founded something new with his study, even if only on the instability of the sea. In the self-defense that makes up Book Fifteen, Boccaccio will go on to set the terms for his own version of the recovery of ancient culture, which is founded on the privileging of Greek sources and on the coexistence of Greek, Latin, and the vernacular in a cosmopolitan cultural network, ${ }^{2}$ whose openness is its richest virtue. 
The self-defense has been consistently read as a historical defense against the attacks Boccaccio might have suffered as author of a text on pagan gods, ${ }^{3}$ but Vittorio Zaccaria, among many others, has noticed that the insertion of Greek poetry into the Genealogie was Boccaccio's most important innovation, a self-conscious act of novelty, which he defends in Chapter Seven of Book Fifteen. ${ }^{4}$ It was not a mere novelty for novelty's sake, but rather the foundational event that underlies Boccaccio's cosmopolitan vision for the recovery of ancient culture in the Genealogie. By giving precedence to Hellenic culture, Boccaccio sees the Latinity of ancient Rome and its rebirth in fourteenth-century Italy as developments of a much older tradition that descends from primitive myths. Although Boccaccio tried to learn Greek late in life in order to read Homer, since his actual knowledge of the Greek language remained extremely limited, he engaged with Greek culture primarily through modern Greek scholars such as Leontius Pilatus, who provided him with an interlinear Latin translation of Homer's two poems, and Barlaam of Seminara, whom he held as an expert on the Hellenic world, and through other philhellenic Latins, such as Paolo da Perugia and Theodontius. ${ }^{5}$ Boccaccio's Hellenism, derived both from direct and indirect knowledge of the Greek language and culture, was not only the foundation of his perspective on the past, but also the basis for his defense of novitas, or modernity, tout court, from Greek and Arab science to vernacular poetry. ${ }^{6}$ In this sense, then, Boccaccio's openness to Greek culture, both scientific and poetic, along with the commentary tradition through which it was known in Latin Europe, starkly contrasts with Petrarch's direct and exclusive engagement with the Roman world. ${ }^{7}$

The project of cultural renewal at the heart of the Genealogie has generally been read, however, as the result of a turn in Boccaccio's career toward Petrarchan Latinity. ${ }^{8}$ In order to appreciate Boccaccio's foundational defense of the work and its novelty, we must consider the Genealogie in the light of Petrarch's project of renewing Roman culture. Both Petrarch and Boccaccio are interested in the recovery of the ancient past for the purposes of the present and future, but they are separated in their efforts by a fundamental difference of approach, which is indicative of a deeper difference of opinion about the role that ancient culture should play in the modern world and even about the nature of culture itself. In the Genealogie, Boccaccio engages with classical Roman authority in an innovative, subversive way that allows him to include both modern and Greek authors among 
the egregi viri whom he cites throughout the treatise. In an effort to understand Boccaccio's criteria for authority, I propose a connection between his recovery of a Greek tradition and his reliance on modern sources for the reconstruction of the ancient past. I argue that his project of renewing antiquity in the Genealogie depends on a notion of historical relationality. According to such an idea, culture-whether inherited from the past or produced in the present-is conceived of as a network of relations, whose nature changes according to the subject's historical perspective. Thus, as an alternative to Petrarch's monumental new Roman antiquity, I show that Boccaccio founds a generative vision of culture that refuses to monumentalize the past or the humanist himself as a promoter of the past.

Petrarch has often been championed as the first of the moderns, ${ }^{9}$ primarily due to his sense of the historical fracture between the modern and ancient worlds. Petrarch's effort to overcome such a rupture can be seen in his self-conscious reworking of a restricted number of Roman authors: Cicero, Virgil, Horace, et al. The strategy that he adopts in order to bridge this historical gap involves turning imitatio into a stylistic competition with these Roman auctores, each of whom he refashions in his memory. ${ }^{10}$ From such an agon Petrarch emerges victorious as the standard bearer of a new antiquity. For Petrarch, then, I understand modernity as a question of memory and style-as a monumentalization of the past. For Boccaccio, who was just as self-conscious of his age's historical isolation from antiquity, ${ }^{11}$ modernity can be understood in terms of the fluid, generative relationship that he establishes between past and present through a process of critical historicization. ${ }^{12}$ His willingness to integrate new phenomena-such as Greek and Arab science and Florentine vernacular poetry-within a holistic vision of culture that nonetheless reflects historical difference represents a divergent model for overcoming the historical isolation of the modern world.

The fundamental difference between Boccaccio's and Petrarch's notions of renewing antiquity, and therefore their self-consciousness of their own novelty, is highlighted by Boccaccio in a comparison of the divergent qualities of their memory and talent. In the first Proem to Book One of the Genealogie, Boccaccio points out to Donnino da Parma, emissary of Boccaccio's patron, King Hugh IV, that Petrarch is more suited to the collection and redaction of ancient poetic material because he is "celesti ingenio preditus et perenni memoria [endowed with a celestial talent and eternal memory]," whereas 
Boccaccio defines himself as having an "ingenium tardum et fluxa memoria [late-coming talent and a fluid memory]." 13 The adjectives used to describe Petrarch's memory and creative impulse (perennis and celestis) signal a removal from the fluctuations of history and the monumentality of Petrarch's reappraisal of the past. Those used to describe Boccaccio (fluxa and tardum), however, mark by contrast a historical subjectivity and the porous, liquid nature of Boccaccio's cultural renewal in the treatise. Boccaccio seems to say that if Petrarch, in his Latin works, creates a monument to the past, a monument that becomes the foundation for his own self-fashioning as a modern author, then Boccaccio himself will offer an approach to the classical tradition that opens humanistic study to the encyclopedic diversity of human experience. If Petrarch's Rerum Vulgarium Fragmenta stages the precariousness of the modern self on the stormy seas of history, desperately in search of a port, in his Latin works Petrarch poses publicly as the poet-scholar who is capable of establishing the new on the solid ground of memory. Boccaccio, on the other hand, challenges Petrarch's public posture of stability and seeks to found a new vision for culture by anchoring his ship on the fluctuating seas of the present. ${ }^{14}$

In the first part of this essay I will analyze an episode from Boccaccio's initial inquiry into the first pagan god to show both how he is aware of the historical isolation of modern man and how he uses Greek culture to authorize modern inquiry at the expense of Roman authority. In the second part, I will follow Boccaccio's contrast of the two modes of remembrance and creativity in order to show that the result of Boccaccio's Hellenism in the Genealogie is a new vision of the place of ancient culture within the modern world-a Boccaccian cultural politics in which ancient and modern, East and West, co-inhabit the living civic body of Florence..$^{15}$ Boccaccio's dedication to the city of Florence, with all of its imperfections, will be juxtaposed to the exclusivity of Petrarch's republic of letters, which centers around the Aretine poet as a citizen of a phantasmatic new Rome. Unlike Petrarch, who engaged with the ancient in a struggle for primacy and created a vision of the modern as a stylized version of a monumental past, Boccaccio founds his project of cultural renewal on the appreciation of the continuity of culture within a historicized network of relations capable of including even the very monuments made by Petrarch, his lifelong friend. What emerges from my analysis of Book Fifteen in the context of the correspondence between the two 
friends is an intense, animated debate on Greco-Arabic science, the importance of Homer, and the present fate of culture. Boccaccio's Hellenism distinguishes him both from the Latin Petrarch and from the persistent idea of a Boccaccio medievale, ${ }^{16}$ to which readers of Boccaccio have grown accustomed over the years.

\section{The Antiquity of Modernity: History, Perspective, and Authority}

Long before his defense of Greek poetry and modern sources in Book Fifteen, Boccaccio establishes the relationship between ancient and modern authority in the Second Proem to the First Book. ${ }^{17}$ About to set out on a novum iter, or new path, in the same boat that he anchors in the Proem to Book Fifteen, Boccaccio projects with his mind's eye and views the entire circuit of the world. ${ }^{18}$ From this vantage point, he consults a handful of Greek philosophers-Thales, Anaximenes, Chrysippus, and Alcmeon-whom he acknowledges as trustworthy witnesses to the truth of ancient religion, which began with the worship of a prime-mover. Each philosopher, whom he knows from Cicero's treatise De Natura Deorum, ${ }^{19}$ is attributed a certain historicized authority, or gravitas, ${ }^{20}$ which is grounded in the perception of the man and of his learning in his own epoch. In addition to these Ciceronian Greeks, Boccaccio encounters the Roman philosopher Macrobius ${ }^{21}$ and the modern scholar Theodontius, ${ }^{22}$ as he seeks to identify the first of the pagan gods. After questioning each of them about which god they think was the creator of all things, Boccaccio rejects all of the ancient opinions for the modern man's conjecture, for which Theodontius names no authority. ${ }^{23}$ In this dramatization of the relationship between ancient and modern authority, Boccaccio reverses the connection between antiquity and modernity by making authority a question of historical perspective, not of chronological antecedence.

In the imaginary conversations with these men, who collectively represent Greek wisdom as received through the works of Cicero, the five ancient Greeks respond respectively that the first god was water (according to Thales), air (according to Anaximenes), fire (according to Chrysippus), the entire heavens (according to Alcmeon), and merely the sun (according to Macrobius). ${ }^{24}$ In the first redaction of his life of Dante, written in the early 1350s, Boccaccio had already developed a history of poetry that began with a reflection on the 
elements. ${ }^{25}$ Here, by attributing to specific thinkers the belief that God consisted in one of the elements, Boccaccio is associating individual intentions to the history of poetry and thus further historicizing ancient belief. Attached to these intentions is each philosopher's claim to epistemological authority, which Boccaccio depicts as historicized. For example, Boccaccio's description of Thales grounds the Greek thinker's intentions and authority in his own age and simultaneously relates it to the contemporary world: "suo evo sapientissimum hominem et celo astrisque familiarissimum et quem ego audieram multa de vero deo ingenio magis quam fide iam dudum exquisivisse [the wisest man of his era, most knowledgeable about the sky and stars. I had heard that long ago he had made many inquiries about the true god, albeit more by natural ability than by faith]." ${ }^{26}$ Boccaccio qualifies Thales's wisdom by prefacing it with the temporal marker suo evo; Thales was the wisest, but in his own era, whereas Boccaccio's recognition that the philosopher's authority was not based on faith alienates Thales from the modern world. Thales's thought is relegated to the past and is rooted in a personal human experience. Modernity, represented by Boccaccio's perspective on the ancient world, receives Thales's wisdom, from which his gravitas derives, in different terms from those in which it was perceived in antiquity. When Thales responds to Boccaccio's question, he uses human experience and bodily metaphor to explain his opinion: "[aquam] omnia producentem nec aliter quam apud nos plantas humectet, sic ex abisso scaturiginibus emissis in celum usque, sydera et ornatum reliquum manu madida fabricasse [(water) produces everything much as it does in moistening our plants. Spring waters from the abyss were sent into the sky and formed the stars and the rest of the cosmos with its moist hand]." ${ }^{27}$ In Boccaccio's rendition of the Greek philosopher's response, Thales's use of the personal pronoun, which reduces the cosmic to the quotidian, and his attribution of a moist human hand to the element of water demonstrate the limitations of the human perspective behind his philosophy when perceived by the modern investigator. Boccaccio does not undermine Thales's authority as such, but he does locate it historically by placing the philosopher's interpretation within a history of authority, which the modern investigator defines and qualifies in relation to himself.

Likewise, the other ancients are presented in a historicized order of authority: Chrysippus was "inter priscos famosus homo [well known among the ancients]" ${ }^{28}$ as Macrobius will be "iuniorem 
omnium [the youngest of all]." ${ }^{29}$ Each of the philosophers represents a certain limited point of view: Anaximenes claims that air was the first mover because living beings cannot live or procreate without air; Chrysippus similarly notes that fire must be the creator of all things because nothing can be born or survive without heat. The gravitas of these philosophers-the weight of their authority-is grounded in their attachment to a personal perspective relegated to their own time. Wtih Alcmeon, Boccaccio stages the reductio ad absurdum of the weight of ancient authority. He describes Alcmeon as hovering above the earth and flying among the stars, where the Greek philosopher gathers inaccessible knowledge:

Alcinoum autem Crotoniensem cum convenissem, ceteris celsioris animi hominem comperi. Nam elementis transvolatis repente intellectu se miscuit astris, inter que, que noverit nescio, sed retulit se arbitrari solem, lunam et stellas et omne celum rerum omnium fuisse fabros. O liberalis homo! Quam uni tantum elemento ceteri dederant, hic omnibus supercelestium corporibus deitatem largitus est.

[When I addressed Alcmeon of Croton, however, I found a man of loftier thought than the others, for after having flown across the elements he suddenly mingled his mind with the stars, becoming familiar with I know not what, but he reported that he thought that the sun, moon, and stars and the entirety of the heavens were the makers of all things. Oh generous man! The divinity the others attributed to only a single element, he bestowed upon all the supercelestial bodies. $]^{30}$

Alcmeon represents a kind of human perspective that raises itself up to the stars, making the universe itself dependent on man's contemplation. In a mockery of generosity, the philosopher distributes divinity liberally to all of the heavens. As his mind departs from the terrestrial origins of human thought and mixes with the stars, the weight of his authority becomes ironically and ridiculously light, lacking any gravitas. Furthermore, as represented by Boccaccio, Alcmeon's intellect has become so far removed from human experience that Boccaccio cannot know what he has found among the 
stars. The modern investigator's disenchantment and doubt cast a shadow over Alcmeon's authority in the new epoch.

The last of the ancient philosophers interrogated here is the fifth-century Roman, Macrobius, who reins in Alcmeon's generosity by attributing divinity to the Sun alone. If the first three philosophers grounded their authority in the human experience of the world, and Alcmeon transgressed the boundaries of human authority, Macrobius represents the self-containment of a proto-Christian Latin philosophical authority. With Macrobius and the four Greek philosophers, Boccaccio has given voice to the reception of Greek thought through Roman philosophy. The four Greeks are related to Macrobius through Cicero's philosophical works, inasmuch as the former were received by the Latin West through Cicero's De Natura Deorum, whereas Macrobius himself aided in the reception of Cicero in his commentary on the Somnium Scipionis. These figures, when taken together, represent a model for the reception of Greek culture through Latinity. ${ }^{31}$ Cicero, a figurehead for Roman culture both in the medieval and humanist worldviews, distills the philosophical thought of the Greeks, corrects it, and transmits it to Macrobius, who would become central to the medieval reception of Greco-Roman philosophy and Neo-Platonic mythical discourse. By historicizing the process of the reception of Greek authority and by dramatizing that authority in individuals with historicized intentions, Boccaccio casts a shadow of doubt over the ideology behind a solely Roman reception of Greek antiquity. In its place, he will go on to suggest an alternative reception that displaces the centrality of Latinity in general.

After hearing from Macrobius, Boccaccio consults the modern Theodontius, who answers the same question as the others from a different point of view:

Theodontius vero, ut arbitror, novus homo sed talium investigator precipuus, neminem nominando respondit: "vetustissimorum Arcadum fuisse opinionem terram rerum omnium esse causam, eique, ut de aqua dicit Thales, mentem inesse divinam existimantes, crediderunt eius opere omnia fuisse producta atque creata."

[Theodontius, who, I believe, is a modern man (novus homo), but a distinguished investigator in such matters, responded without naming anyone: "It was 
the opinion of the most ancient Arcadians that earth was the origin of all things; as Thales said regarding water, they proposed that it contained a divine intelligence, which they believed produced and created everything." $]^{32}$

Theodontius does not give his own opinion, but merely reports what ancient Arcadians must have believed. His historicized response belongs to a post-mythic era, in which belief in the gods no longer obfuscates historical or philosophical investigation. ${ }^{33}$ From the privileged historical perspective afforded by his modern disenchantment, Theodontius responds by taking into account the original beliefs of the most ancient Greek peoples- the so-called Arcadians. He is able to abstract himself from his own period, and its preconceptions, and to present what he believes to be the most ancient point of view. He looks beyond any previous scientific meaning of myth and beyond all poetic texts to the intentions of primitive man himself. His response represents authority as a question not of the historical antiquity of the source, but of the perspective that the source provides on antiquity. Unlike the others, whose authority is based on a personal, historicized gravitas that gradually becomes detached from human experience, Theodontius derives his authority from the post-mythic, anthropological perspective that he provides on the historical continuum of authority-much like Boccaccio, who views the extent of the world from the perspective of his mind's eye. ${ }^{34}$ The question of ancient authority is complicated by Boccaccio's sense of history, which overturns the typical relationship between ancient and modern authorities. ${ }^{35}$ This episode implies that the modern source, with his privileged knowledge of Greek culture and of antiquity in general, can redefine the Latin reception of Greek culture, thereby qualifying the authority of Roman authors in relation to their past and their future. The perspective provided by modern authorities becomes necessary for recuperating the past in a productive manner.

Following Theodontius, Boccaccio is able to imagine retrospectively the religious beliefs of antiquity—a specifically Hellenic antiquity-as a cultural production that anteceded poetic authorities such as Ovid, Virgil, or even Homer, themselves nodes in the midst of a poetic network. At the same time he also detaches his critical perspective from the philosophical ideologies of the allegorizations of Macrobius, Claudian, Martianus Capella, and others who 
helped found new Christian uses of myth. In the Genealogie, ancient and modern philosophical and poetic authorities represent specific times and places in a genealogical network: there is no longer an absolute poetic authority. Theodontius, thus, cites no one, since there is no source that precedes the opinion of the most ancient Greeks, whom he figures in his historical imagination. Boccaccio is not entirely irreverent of the other philosophers' opinions, nor does he merely dismantle the foundations of their authority as it is received by the Latin West through the works of Cicero and Macrobius; on the contrary, he is able to revise his own relationship with ancient authorities by representing them in their own place and time from the point of view of the future-from Boccaccio's own present-day. The novitas of the modern researcher is equal to and even surpasses the authority of the ancient. From the novel perspective provided by modernity, Boccaccio can discern and reconfigure the channels of reception through which he accesses the past.

Throughout the Genealogie, Boccaccio will continually make reference to Theodontius as a source for Hellenic mentalities and stories, and he will refer to what he has learned of the Greeks from his teachers-Paolo da Perugia, Barlaam of Seminara, and Leontius Pilatus-often citing Leontius's translations of Homer, but just as often reporting from these men fables that represent ancient Greek popular belief. Boccaccio's recovery and renewal of antiquity is founded upon the radical overturning of authoritative perspective, and will privilege Greece as the birthplace of ancient culture, both high and low, as it is transmitted across time and space in a historical network that relates Greeks, Arabs, Romans, and contemporary thinkers and poets to one another. ${ }^{36} \mathrm{He}$ finds that modern authors are just as trustworthy as ancient ones in this process, if not more so, since they are self-conscious of their place in the continuum of culture. Between the Hellenic world, as Boccaccio imagined it, and his own day there is a divide that can be bridged only by a process of historicization that relates the past to the present in a genealogical network. ${ }^{37}$

\section{Boccaccio's Greeks and the Future of Humanism}

Boccaccio's radical revision of ancient authority culminates in his defense of it in two consecutive chapters of the final book of the Genealogie: the sixth, in which he defends his use of modern 
authorities, and the seventh, in which he defends his use of Greek poetry. It is important to keep in mind that the intended audience of the self-defense is composed not only of zealots who would criticize his pagan subject of study, but also of "omnes honestos, sacros, pios atque catolicos viros, et potissime celebrem virum, Franciscum Petrarcam, insignem preceptorem virum [all honest, holy, devout Catholic men, and particularly my eminent teacher, the far-famed Francis Petrarch]." ${ }^{38}$ In the defense of his work, and especially in his justification of both his modern and his Greek sources, Boccaccio defines his own vision for the modern recovery of antiquity, which diverges in many ways from that of his teacher.

This divergence manifests itself most clearly in Boccaccio's Hellenism and in the value that he ascribes to modern sources of scientific, poetic, and historical knowledge. In his defense of Greek against an obstinate Latinity, he summarizes the structural idea of originality with which he challenges the hegemony of a solely Latin and Roman cultural history: "Dico igitur, si nesciunt carpentes immeritum: 'Insipidum est ex rivulis querere quod possis ex fonte percipere' [Let me say then for the enlightenment of those unworthy slanderers, that it shows a lack of judgment to derive from the stream what may be got at the fountainhead]." ${ }^{99}$ This overt declaration of method points out the derivative nature of Roman letters and, thus, puts into question the authority of Latinity as a source. Yet, it also ironically coincides with Boccaccio's choice of following the modern scholar, Theodontius, over the Ciceronian Greeks in the second proem to the first book. By establishing Greek as the genealogical source of culture (the fons from which diverse rivuli spring forth), Boccaccio deauthorizes Latinity and makes room for further divarication. In this way, his genealogy is both a critical history of culture that points out false and true origins and a generative history of culture that allows for the birth of the new in a living world.

Knowing that the proponents of Latin letters would not receive well his recourse to Greek poetry, Boccaccio clarifies his intentions:

Ast ego in hoc Latinitati compatior, que sic omnino greca abiecit studia, ut etiam non noscamus caracteres licterarum. Nam, etsi sibi suis sufficiat licteris, et in eas omnis occiduus versus sit orbis, sociate Grecis lucidiores procul dubio apparerent. Nec preterea 
omnia secum a Grecia veteres traxere Latini: multa supersunt, et profecto nobis incognita, quibus possemus scientes effici meliores.

[I am sorry then for Latin learning, if it has so completely rejected the study of Greek that we do not even recognize the characters. Though Latin literature may be sufficient unto itself, and may enjoy the exclusive attention of the whole western world, yet without question it would gain much light through an alliance with Greek. Besides the ancient Latin writers have not by any means appropriated all that is Greek. Much yet remains unrevealed to us, and much by knowledge of which we might profit greatly.] ${ }^{40}$

Although Boccaccio gives Latin literature its due, he wholeheartedly supports the importance of the Hellenic tradition because it represents a missing link in the cultural history of the Western world. He complicates the transmission and reception of Greek culture through Latin authorities, much in the same way as he had dramatized reception in the second proem. He feared the reaction of proponents of Latin culture, such as Petrarch, because Greek sources, from a certain point of view, would make Latin appear derivative despite the self-sufficiency that it had acquired.

Such a direct declaration of the value of Greek is in dialogue with, if not direct opposition to, Petrarch's representation of Latin and the Roman world as the culmination of civilization, which he expresses unequivocally in a 1370 letter to Giovanni Dondi da Padova. In this letter Petrarch criticizes physicians' excessive deference to Greek authorities (Seniles XII, 2):

Ergo post Platonem atque Aristotilem de rebus ad omnem philosophie partem spectantibus Varro et Cicero scribere ausi sunt. Post Demosthenem de rebus ad eloquentiam pertinentibus Cicero idem, post Homerum poetice scribere ausus est Maro; et uterque quem sequebatur aut attigit aut transcendit. Post Herodotum et Tuchididem Titus Livius et Crispus Salustius historias conscripserunt et illos a tergo quam longissime reliquerunt; post Lycurgum et Solonem legesque duodecim tabularum, nostri 
iurisconsulti, de tam paucis granis in sulcos grecorum ingeniorum parte adeo effusis, legum civilium tam opimam messem in horreum romane reipublice congesserunt, ut in eo studio facile ostenderent se victores. Post mathematicos graiorum scribere noster non timuit Severinus [Boethius]; post illorum quattuor theologos nostri totidem sic scripserunt ut sine contradictore superaverint. Post solos Arabes scribere non licebit? Denique Grecos et ingenio et stilo frequenter vicimus et frequenter equavimus, imo, siquid credimus Ciceroni, semper vicimus ubi annisi sumus; quod, si vere de nobis in comparationem omnium aliarum gentium dici potest, Arabiculis, ut vos velle videmini, duntaxat exceptis. O infamis exceptio vel extincta! Singulariter ingenium tuum fleo his angustiis circumseptum.

[Thus, after Plato and Aristotle, Varro and Cicero dared to write on matters dealing with every area of philosophy; after Demosthenes, Cicero did the same with things pertaining to eloquence, and after Homer, Maro dared to write poetry; and each Latin writer equaled or surpassed the one he followed. After Herodotus and Thucydides, Titus Livy and Sallustius Crispus wrote histories, and left their predecessors far, far behind. After Lycurgus and Solon and the laws of the Twelve Tables, our jurisconsultsfrom so few seeds sparingly sprinkled in the furrows of Greek minds-gathered such a rich harvest of civil laws into the storehouses of the Roman Republic that they easily showed themselves the victors in that field. After the mathematicians of the Greeks, our own Severinus (Boethius) did not fear to write. After their four theologians, our four wrote in such a way that they surpassed them by common consent. Is it only after the Arabs that no one will be allowed to write? In short, we frequently overcame the Greeks in talent and style, and we frequently equaled them; or rather, if we trust Cicero, we always won whenever we competed; if such a great man has truthfully said this about us in comparison with the Greeks, it can be said with much greater 
confidence in comparison with other peoples, that is, except those measly Arabs as you would have it. $\mathrm{O}$ infamous exception, $\mathrm{O}$ marvelous dizziness of things, O Italian intellects benumbed or quenched! I singularly weep over your talent, hemmed in by such narrowness. $]^{41}$

For Petrarch, the Romans (among whom he includes himself) were always superior to the Greeks. By connecting himself to this Roman legion of philosophers, orators, poets, historians, lawmakers, mathematicians, and theologians, Petrarch arms himself with a weight and authority won on the battlefields of intellectual history. In this defense of his own novelty-a new Roman antiquityPetrarch appropriates the Roman past in order to exclude and reject the changing patterns of knowledge represented by the influx of Arab learning into Europe. ${ }^{42}$ In fact, Petrarch's notion of classicism even considers imitation as a form of competition, as a historical struggle, that resulted in the Romans overcoming the Greeks precisely by copying them and making them better in a stylistic refashioning. ${ }^{43}$ As he writes to Boccaccio himself in 1359 (Familiares XXII, 2): ${ }^{44}$

Etsi enim non me lateat quosdam veterum Virgiliumque ante alios versus innumeros non modo e greco in latinum versos ... sed, ut erat, ex alienis in suum opus transtulisse, non ignorantia quidem ulla . . neque furandi quantum intelligitur, sed certandi animo ... certe ego, si res adigat, alieno sciens uti patiar, non comi; siquid adversus hec ab ignorante peccabitur, fac sentiam.

[Although I do know that some ancient writers, Virgil in particular ... not only translated innumerable verses from Greek into Latin, but transferred them from foreign works into their own, not out of ignorance ... nor, one gathers, for the sake of stealing, but rather for the sake of competing .... As for me, if forced by necessity, I would allow myself to use another's words consciously, but not for mere decoration. If out of ignorance I ever do sin against this principle, make certain that I hear about it. $]^{45}$ 
Although Petrarch excludes himself from this agonistic system of imitation, it is clear from works such as the Africa and the Bucolicum Carmen, which is the subject of this letter, that he borrowed from Virgil, Ovid, and others out of competition just as liberally as he saw the Romans taking from the Greeks. ${ }^{46}$ For Petrarch, the agon of literary history was won by style, an element that defines his own modernity. Thus, by insisting that Latin letters could benefit from the study of Greek, Boccaccio not only revolutionizes the sources for understanding ancient culture, but more importantly he displaces the authority of Latin, which, according to Petrarch, had been won in a struggle with the Greek heritage. Boccaccio places Latin and the Roman auctores in a historicized network of cultural transmission that links them to a past and a future, making them interdependent and no longer self-sufficient.

Boccaccio claims that he had hoped to bring honor to Latin by relating it to Greek, but he laments that his efforts were received with envy: "Rebar equidem aliquid Latinitati decoris afferre, ubi in me livoris nebulam excitasse video [I thought I was adding a certain grace to Latin learning, yet I see that a cloud of envy (livor) has moved against me]." ${ }^{47}$ This livor, which is not merely envy, but really hatred ${ }^{48}$ arises not only because of the incomprehensibility of Greek to his Latinate audience, but also because in the eyes of scholars such as Petrarch, Greek threatened the status of Latin as the language of the fathers. In this way, by making Roman culture the relative of the Greeks, Boccaccio also makes room for modern sources, including vernacular literature in a new, open literary and scientific canon. In the cultural network between East and West, Boccaccio can collocate Latin poetic authorities and Roman culture according to the same genealogical paradigm that connects Greek fables to modern scientists like Andalò del Negro and Paolo Geometra and to vernacular poets such as Dante and Francesco da Barberino, and even to Petrarch himself, the authority of each of whom Boccaccio had defended in the preceding chapter, alongside three scholars of Greek culture.

Thus, by arguing that Greek poetry could enrich Latinity, Boccaccio justifies his openness to modern authorities, linking the arguments of Chapter Seven and Chapter Six of Book Fifteen. In fact, the two chapters are bound, at the end of Chapter Six, by a defense of "other" ancient authors, ${ }^{49}$ or incogniti antiqui, against those who "dicent igitur . . . me inauditos a se inducere autores, quasi, quia eorum nomina non audiverint, non illis integra prestanda sit fide 
[charge me with citing authors they never heard of, as if none were trustworthy whose names they have never heard]. ${ }^{50}$ He claims that it is not the fault of these authors that they are not well known in modern times, as "non enim possunt volumina e bibliothecis in manus evolare torpentium [the books themselves cannot of their own accord take wing from the libraries into the hands of sluggards]." These books, he says, like the Holy Scriptures, the codices of law and medicine, the tomes of the philosophers, and the schoolbooks of the arts, need commentary in order to make an impact on a community of scholars and acquire a modern voice: "sola poesis . . . his caret subsidiis [poetry alone is without such honor]. ${ }^{\text {" } 2}$ Whereas Boccaccio would raise these minor authors to the level of canonical Roman auctores, Petrarch, as he once wrote to Boccaccio (Familiares XXII, 2), separated ancient writers into two categories defined by their place in his memory: those authors whom he had read just once and from whom he thus remembered little, and those with whom his familiarity was such that he became of one body and mind with them:

Legi semel apud Ennium, apud Plautum, apud [Martianum] Felicem Capella, apud Apuleium, et legi raptim, propere, nullam ibi ut alienis in finibus moram trahens. Sic praetereunti, multa contigit ut viderem, pauca decerperem, pauciora reponerem, eaque ut communia in aperto, et in ipso ut ita dixerim memoriae vestibulo .... Legi apud Virgilium, apud Flaccum, apud Severinum, apud Tullium; nec semel legi sed milies, nec cucurri sed incubui, et totis ingenii nisibus immoratus sum .... Hec se mihi tam familiariter ingessere, et non modo memorie sed medullis affixa sunt unumque cum ingenio facta sunt meo, ut etsi per omnem vitam amplius non legantur, ipsa quidem hereant, actis in intima animi parte radicibus.

[Only once have I read Ennius, Plautus, Martianus Capella, and Apuleius, and then it was done hastily and quickly, brooking no delay except as one would in unknown territory. Proceeding in this fashion, I saw many things, culled a few, retained even fewer, and these I laid aside as common property in an open place, in the very atrium of my memory ... . I have read Virgil, Horace, Boethius, Cicero not once but 
countless times, nor did I rush but I brooded, pondering them as I went with all the powers of my intellect .... I have thoroughly absorbed these writings, implanting them not only in my memory but in my marrow, and they have so become one with my mind that were I never to read them for the remainder of my life, they would cling to me, having taken root in the innermost recesses of my mind. $]^{53}$

The process by which Petrarch excludes certain authors from his memory is precisely what Boccaccio is undoing in these two books on modern and Greek sources. Boccaccio is evoking a kind of cultural memory that lives not in the memory of the single scholar, which divides and excludes, but one that propagates itself in the civic and university centers of the Italian peninsula and of the known world. Of course, the exclusivity of Petrarch's engagement with antiquity is a sign of his own monumental modernity. ${ }^{54}$ Connected with the development of the private, individual self, Petrarch's relationship with antiquity is defined by a principle of exclusion. Boccaccio, however, represents an alternative modernity that engages with antiquity by confronting and absorbing its difference openly. The historical solitude of the modern individual is obliterated in the name of a self-propagating multiplicity, connected to the medieval notion of universitas, which spans the breadth of space and depth of time.

In the defense of modernity that precedes these incogniti antiqui, Boccaccio argues that the authority of modern authors is comparable to that of ancient authors:

nam quantumcunque novi fuerint qui nunc ex autoribus veteres sunt, videtur quod per multa secula perseveratum est, a longitudine temporis approbatum sit, et inde plurimum autoritatis sumpsisse. Quod utrum de omnibus novis, quantumcunque bene sint meriti, arbitrari debeat, apud multos videtur in pendulo. Ego autem huius sententie sum, nunquam in evum duraturos hos quorum novitas approbata non sit, cum ab eorum novitate necesse sit exordium approbationis sumendum; et sic eos, quos ego novos invoco, cum vivos noverim aut noscam, meritis eorum agentibus, egregios esse viros atque probandos 
ausus sum in testimonium evocare. Hoc enim michi constat ex ominibus, eos fere per omne vite tempus studiis vacasse sacris, eos inter insignes scientia et moribus semper versatos homines, eos vita laudabiles, nec ulla turpi nota signatos, eorum scripta aut dicta a prudentioribus etiam approbata. Credo, his agentibus, equiparanda sit eorum novitas vetustati.

[However modern those authors who are now ancient once were, it seems that whatever has survived through many ages has been approved by a great lapse of time, and thence gains most of its authority (auctoritas). But what one ought to think about all moderns, whatever their merit, seems to many to be still in suspense. I am of the opinion that no writer will last long whose very novelty is not approved, since approval must be born from their novelty itself. Thus I have dared cite as my authorities moderns whom I have known or know personally, or whom by their merits I recognize as exceptional men, worthy of approval. It is clear, about all of them, that they always frequented men famous for their learning and character, that they were praiseworthy in life, unmarked by any turpitude, and that both their writings and sayings have been approved by the wisest men. I think for these reasons that modernity must be held as equal to antiquity. $]^{55}$

Boccaccio believes that the moderns can have an authority that parallels that of ancient auctores because he knows with more certainty the qualities of these men and the merits of their work. The continual repetition of words with the root probare, which conveys a meaning similar to our own word "to prove," or more precisely "to test or examine by trial," makes authority a matter of experience. For the ancients the authority of experience lies in a posthumous survival over time after an initial testing of their novelty. For the moderns, the living proof of the men's experience in life acts as a guarantee of their future promise. Boccaccio is willing to gamble on the moderns (ausus sum) because of the certainty provided by experience, rather than merely place his trust in the time-tested authority of the ancients. There is an ethics of authority in this passage that is founded on the connections of modern men to Boccaccio and his 
own time. The ancients, he reminds his readers, were novi, or modern, in their own time and first had to survive their own age before they could produce offspring among posterity. By gauging modern men according to the criteria by which ancient authors first survived, Boccaccio realigns the relationship between the old and the new and links their authority.

Boccaccio then opens a list of examples that begins with Genoese astrologer Andalò del Negro, ${ }^{56}$ whose authority is based not only on his knowledge of ancient science, but on the weight of the certainty that he gains through experience. Boccaccio makes a radical claim to his authority that aims at the foundations of Petrarch's idea of culture, invoking his patron, King Hugh IV's personal acquaintance with the astrologer:

Induxi igitur sepe generosum atque venerabilem senem, Andalo de Nigro ianuensem, olim in motibus astrorum doctorem meum, cuius quanta fuerit circumspectio, quanta morum gravitas, quanta syderum notitia, tu nosti, rex optime; tibi enim, ut aiebat ipse, cum adhuc iuvenis esses, ratione conformitatis studiorum familiarissimus fuit, et, ut ipse vidisse potuisti, non solum regulis veterum, sed, cum universum fere peragrasset orbem, sub quocunque climate, sub quocunque orizonte, experientia discursuum certior factus, visu didicit quod nos discimus auditu. Et ob id, etsi in omnibus illi fidem prestandam crediderim, circa ea tamen, que ad astra spectare videntur, non aliter quam Ciceroni circa oratoriam aut Maroni circa poeticam exhibendam censeo.

[I have frequently cited that generous and venerable old man, Andalò del Negro of Genoa, who was once my teacher of astronomy. You know well, O excellent King, how much circumspection he had, how much authority (gravitas) he gained from his manner of living, and how much he knew about the stars. He was, as he used to say, very intimately associated with you, through similarity of studies which you pursued when a young man. You could see for yourself that he not only knew the motions of the stars according to the laws of the ancients-which is our way of 
learning them-but he had travelled nearly all over the world, visiting every clime and horizon, and he became more certain thanks to the experience of his travels, learning by seeing what we learn by hearsay. I would have thought to trust him on all matters, but particularly on everything pertaining to the stars, just as I judge that we should trust Cicero on oratory or Virgil on poetry. ${ }^{57}$

Boccaccio reveres the old astrologer, whom he knew as a young man in Naples, for the knowledge of the stars that he had gleaned from his experience. The Genoese scientist is even more authoritative than his ancient sources, since he observed with his own eyes the movements of the stars. Boccaccio's reverence for his old teacher derives from the king's and his own firsthand knowledge of the astrologer's circumspectio and gravitas, terms that together render the perspective of modernity synonymous with its authority. The comparison to Cicero and Virgil, with which Boccaccio concludes his justification of Andalò del Negro, may be taken as a general response to Petrarch's distrust both of astrologers in general and, specifically, of those new thinkers who incessantly speak of the Greeks and assert an authority that is comparable to, but detached from, Roman authors.

In a 1364 letter to Boccaccio in which Petrarch insinuates that Boccaccio's overly affected humility is actually a sign of pride (Seniles $\mathrm{V}, 2$ ), Petrarch describes a discussion that took place in his library with "unus . . moderno more phosophantium [one . . of those who philosophize in the modern fashion]." ${ }^{58}$ Petrarch eventually expels the philosopher from his library, when he attacks the value of Saint Paul and Saint Augustine. Petrarch's indignation in the paragraph that follows this description is indicative of his general approach to science and to the kind of modernity represented by new knowledge:

In hoc tempus incidimus, amice, in hac vivimus iamque senescimus etate, interque hos iudices-quod sepe queri soleo et indignari-quos, scientie vacuos ac virtutis, falsa sui implet opinio, quibus libros veterum perdidisse non sufficit nisi ingeniis ac cineribus decertent et, ignorantia sua leti, quasi quod nesciunt nichil sit, pingui et tumido lasciviunt intellectu, novos vulgo auctores et exoticas invehunt disciplinas. 
[These are the times that we have fallen into, my friend, this is the age in which we live and now grow old, among such judges, bereft of any knowledge or virtue and inflated with a false opinion of themselves, as I complain and rage about so often. For them it does not suffice to have lost the books of the ancients, they must vie with their genius and ashes; and happy in their ignorance, as though what they do not know were nothing, they give free rein to their greasy, swollen intellects, they introduce new authors right and left, and exotic disciplines. $]^{59}$

In the hyperbolic rhetoric of invective, Petrarch situates himself in opposition to modern philosophers, who reject the authorities of Roman and biblical antiquity and become new models ${ }^{60}$ Alongside the novelty of science, with its new authors and exotic disciplines, in the same letter, Petrarch situates the vernacular literature of his youth as a similarly unfounded product of modernity:

at hic [vulgarius stilus], modo inventus, adhuc recens, vastatoribus crebris ac raro squalidus colono, magni se vel ornamenti capacem ostenderet vel augmenti. Quid vis? Hac spe tractus simulque stimulis actus adolescentie, magnum eo in genere opus inceperam, iactisque iam quasi edificii fundamentis, calcem ac lapides et ligna congesseram, dum, ad nostram respiciens etatem et superbie matrem et ignavie, cepi acriter advertere quanta esset illa iactantium ingenii vis, quanta pronuntiationis amenitas, ut non recitari scripta diceres sed discerpi. Hoc semel, hoc iterum, hoc sepe audiens et magis magisque mecum reputans, intellexi tandem molli in limo et instabili arena perdi operam, meque et laborem meum inter vulgi manus laceratum iri. Tanquam ergo qui, currens calle medio, colubrum offendit, substiti mutavique consilium iterque aliud, ut spero, rectius atque altius arripui.

[This vernacular writing, just invented, still new, showed itself capable of great improvement and development after having been ravaged by many and cultivated by very few husbandmen. Well then, this 
hope so attracted me and at the same time the spur of youth so urged me onward that I undertook a great work in that style; and having laid, as it were, the foundations of that edifice, I gathered the cement and stone and wood; I then began to observe attentively our age, mother of pride and laziness, and to notice the great talent of the show-offs, the charm of their elocution, so that you would say the words were not being recited but torn to pieces; hearing this once, twice, many more times, and repeating it to myself more and more, I finally came to realize that it was a waste of effort to build on soft mud and shifting sand, and that I and my work would be torn to shreds by the hands of the mob. Thus, like the runner who stumbles upon a serpent in the middle of the path, I halted and changed my mind, taking another pathway that I hope will be straighter and higher.] ${ }^{61}$

Both the novelty of the vernacular and that of modern science are presented in this letter as products of an age that lacked the stability and style that the model of antiquity could provide. In this public fashioning of his career as a poet and intellectual, Petrarch defends the time-tested value of antiquity in response to those "qui Marcum Tullium Ciceronem, lucidum eloquentie solem, spernunt; qui Varronem, qui Senecam contemnunt; qui Titi Livii, qui Salustii stilum horrent ceu asperum atque incultum [who scorn that bright sun of eloquence, Marcus Tullius Cicero; who despise Varro and Seneca; who shudder at the style of Titus Livy and Sallust, as though rough or uncultivated]." ${ }_{22}$ These iconoclastic philosophers rely instead on "novis ... ducibus pudendis [new models whom they should be ashamed of]" ${ }^{63}$ and even come to shun their own Greek philosophical authorities: "Platonem atque Aristotilem damnant, Socratem ac Pithagoram rident. Et, Deus bone, quibus hec ducibus, quam ineptis agunt! [they condemn Plato and Aristotle, they ridicule Socrates and Pythagoras. And this they do, good God, with what foolish authorities!]." ${ }^{64}$ Petrarch connects the lack of respect for the Roman tradition to the presence of Greek authorities, which permits the modern scientists' ostentation of their novelty and lack of respect for tradition in general, even for the Greeks themselves. 
Petrarch's conception of culture defines itself in contrast to modern philosophers, who scorn ancient authorities, and fashion themselves as new models: "Horum tamen isti nominibus gloriantur relictisque fidis ducibus [the fools gush over them and follow them, deserting reliable models]." ${ }^{65}$ His exaggerated language shows his indignation for those who would reject the authorities of classical antiquity for new models, such as that represented by Andalò del Negro. The terms in which Boccaccio describes the Genoese astrologer, in fact, speak to Petrarch's own preoccupations with the novelty of his age: the astrologer is not foolish and impudent, but prudent and serious, a synthesis of scholarly respect for tradition and the novel quest for knowledge by experience. By beginning his defense of the moderns with Andalò del Negro, Boccaccio immediately takes up arms in defense against Petrarch's indignation with scientific modernity, which was intimately related to Greek and Arabic textual authorities. Furthermore, Boccaccio signals that the main force of his defense is directed at Petrarch's own cult of Latinity.

Linked both to the modern perspective that Boccaccio champions in the second Proem to Book One and to his differences of opinion on culture with Petrarch are the vernacular poets of modernity. Directly following the defense of Andalò del Negro, Boccaccio inserts two vernacular poets-Dante Alighieri and Francesco da Barberino-as examples of how the modern creative impulse follows the trajectory created by the past. ${ }^{66} \mathrm{He}$ first mentions Dante's Commedia as an example of vernacular literature that coincides with divine theology if not myth:

Qualis fuerit, inclitum eius testatur opus, quod sub titulo Comedie rithimis, florentino ydiomate mirabili artificio scripsit. In quo profecto se non mythicum, quin imo catholicum atque divinum potius ostendit esse theologum.

[His greatness is proved by his famous work in rime, which he wrote in the Florentine dialect with amazing skill, and called the Commedia. In that he stands forth rather as a universal and sacred theologian than as a mythical (theologian) $].^{67}$

Dante's great work of poetry acts as a form of collateral that guarantees his quality as a witness to the truth. He represents a poetry that is 
no longer just mythical theology, but universal and Christian-he is the culmination of the genealogical tradition traced in the treatise. After Dante, Boccaccio goes on to defend his use of Francesco da Barberino as a source, although he cites the author only once in the treatise: 68

Qui, et si sacros canones longe magis quam poeticam noverit, non nulla tamen opuscula rithimis vulgari ydiomate splendidis, ingenii sui nobilitatem testantia, edidit, que stant et apud Ytalos in precio sunt. Hic integerrime fidei homo fuit et reverentia dignus, quem cum inter venerabiles non dedignetur Florentia cives, optimum semper et in omnibus fidedignum habui testem et inter quoscunque viros egregios numerandum.

[Though more proficient in knowledge of sacred canons than in the art of poetry, he was the author of several essays in brilliant vernacular verse, which bear witness to the high order of his genius, and are much prized by the Italians. He was a man of purest faith, deserving all reverence, whom Florence did not scorn to include among her honored citizens. I have considered him an excellent and trustworthy authority on all points and worthy of being ranked with any men of distinction. $]^{69}$

Da Barberino, too, represents the convergence of Christian faith and poetry, and it is especially his poetry that testifies to his trustworthiness. Boccaccio places Dante and da Barberino among the ranks of the egregios viros not only because of their ethical qualities, but especially because of the value of their Florentine poetry within a civic context. Dante's civic value was only potential and never actualized, because, Boccaccio writes, he would have certainly been crowned poet laureate had exile not impeded him: "nec quicquam illi lauream abstulit preter exilium; sic enim firmaverat animo nunquam nisi in patria illam sumere, quod minime illi permissum est [nothing but his exile kept him from receiving the laurel crown. He had resolved that he would never accept it anywhere but in his native city, and that he was not allowed to do]." ${ }^{" 0}$ Da Barberino was a scholar of canon law, a discipline that Boccaccio himself had abandoned in 
his youth, and his love poetry converged with his faith to the public approval of the citizens of Florence, again much like Boccaccio himself. ${ }^{71}$ This Florentine vernacular poetry is key to Boccaccio's cultural renewal insofar as it is the language of the economic and political exchanges of the fora that make up the city. Its importance is altogether political. ${ }^{72}$

Petrarch's public lack of consideration for vernacular literature, and specifically for Dante, is well known and needs little comment here ${ }^{73}$ but it is worth mentioning briefly his 1359 letter to Boccaccio about Dante (Familiares XXI, 15) in which he claimed that the Commedia lacked nobility and pandered to the pleasures of the multitude, whereas Petrarch himself and ancient poets, such as Virgil and Homer, sought higher things:

Aut cui tandem invideat qui Virgilio non invidet, nisi forte sibi fullonum et cauponum et lanistarum ceterorum ve, qui quos volunt laudare vituperant, plausum et raucum murmur invideam, quibus cum ipso Virgilio cumque Homero carere me gratulor?

[How can someone who does not envy Virgil envy anyone else, unless perhaps I envied him the applause and raucous acclaim of the fullers or tavern keepers or woolworkers who offend the ones whom they wish to praise, whom I, like Virgil and Homer, delight in doing without? $]^{74}$

In the rest of the letter, Petrarch's public distancing of Dante does not take aim at the subject of his poem, which the Aretine poet recognizes as sublime (nobilis). Rather, it is Dante's style, which is popular (popularis), that creates the risk of the public misunderstanding and misrepresentation of the poet's words and thought. Petrarch, for whom vernacular poetry would remain the voice of the inner self, denies the employment of Dante's poetry in a political context that Boccaccio had tried to initiate in his Vita Dantis. ${ }^{75}$ The way in which Petrarch manages to sidestep Boccaccio's political Dante in this letter shows the extent to which Petrarch is concerned with the vernacular's detrimental effect on his own Latin cultural project. ${ }^{76}$ To include vernacular poetry openly in his vision for culture would bring instability to the foundations of his new antiquity, even his own Fragmenta, which he claims publicly to have abandoned 
to the crowd before passing on to a higher Latin style, although he was actually dedicated to it in private his entire life. ${ }^{77}$

As is clear both from this letter and from the later letter to Boccaccio that I cite above (Familiares XXII, 2), for the Latin Petrarch, a certain kind of novelty, whether vernacular poetry or the new scientific disciplines, has no solid ground on which to stand because it belongs to the shifting sands of the present that threaten his quest for lasting fame. ${ }^{78}$ With an apparent surety that he himself was the first of the three poets and a public lack of concern for competing with Dante, Petrarch tries to fashion his own literary fortune upon the lasting memory of the poets of ancient Rome. It is to Petrarch's concern for the volatility of his own reception in the vernacular that Boccaccio speaks in his defense of Dante and da Barberino, but only in the seventh chapter on Greek poetry will Boccaccio provide the coup de main against the stability of Latin literature as a self-sufficient tradition. Greek literature's ability to undermine Petrarch's public attachment to Latinity will ultimately justify a cultural expansion into all fields of knowledge, including vernacular poetry.

In fact, the link between knowledge of the Greek world and new cultural phenomena becomes clear in the next three examples of trustworthy modern authority. After the defense of the two vernacular authors, Boccaccio turns to a discussion of three scholars, whom he recognizes for their knowledge about the Greek culture. The centrality of Hellenic studies to Boccaccio's project is mirrored by the scholars' consecutive location in the center of the chapter. Connecting the perspective of modernity to the antiquity of Hellenic culture, he first cites Barlaam of Seminara, a learned Basilian monk who had taught Petrarch the Greek alphabet: ${ }^{79}$

grecis licteris adeo eruditum, ut imperatorum et principum grecorum atque doctorum hominum privilegia haberet, testantia nedum his temporibus apud Grecos esse, sed nec a multis seculis citra fuisse virum tam insigni tanque grandi scientia preditum. Nonne ergo huic et potissime in rebus ad Grecos spectantibus ego credam?

[he was so good a Hellenist that he enjoyed privileges at the hands of emperors and Greek princes and scholars, which show that neither in our time, nor for many a century, have the Greeks produced a 
man endowed with such vast and peculiar erudition. Shall I not do well to trust him, particularly in all that pertains to Greek?]. ${ }^{80}$

Paolo da Perugia follows, ${ }^{81}$ who was indebted to Barlaam for his knowledge of the Greeks and who was also Boccaccio's teacher in Naples and source for knowledge of Theodontius's writings:

Hic ingentem scripsit librum, quem Collectionum titulaverat, in quo inter cetera, que multa erant et ad varia spectantia, quicquid de diis gentilium non solum apud Latinos, sed etiam apud Grecos inviniri potest, adiutorio Barlae arbitror collegisse .... ex illo [opere] ... sumpsi, et potissime ea omnia, que sub nomine Theodontii apposita sunt.

[He wrote a huge book which he called The Collections; it included much matter on various subjects, whatever could be found about pagan gods not only from Latin authors, but also from the Greeks, which he probably collected with Barlaam's help . . . . Especially I took from that work all those things set down under the name of Theodontius. $]^{82}$

Paolo da Perugia's Neapolitan openness to Greek culture and his synthesis of Latin and Greek fables in the Collectiones must have exerted a great influence on Boccaccio. The influence is clear in the importance that Boccaccio gives to their common source, Theodontius, as a source for Hellenic mentalities. Leontius Pilatus ${ }^{83}$ a Calabrian Greek, who was also a student of Barlaam, lecturer and translator of Homer in Florence, as well as Boccaccio's personal Greek teacher, is next cited: "uti experientia notum fecit, licterarum grecarum doctissimus [est], et quodam modo grecarum hystoriarum atque fabularum archivium inexhaustum [as experience has made known, (he is) a most learned Hellenist . . . and a fairly inexhaustible mine of Greek stories and fables]." ${ }^{44}$ I will discuss below the particular importance of Leontius as the translator of Homer, but in the economy of his defense of modernity, Boccaccio represents Leontius as the embodiment of a Greek knowledge whose depth has never fully been probed. In the same vein as the Proem to Book Two, where he stages the overturning of ancient authority through the reevaluation of the Hellenic tradition, Boccaccio here acknowledges 
these modern scholars precisely because they offer a privileged perspective on the past, which is unavailable in purely Latin sources themselves.

These men are not just isolated sources of knowledge, however, but intermediaries between the Latin and the Greek worlds. Just as Boccaccio had justified Andalò del Negro's gravitas by relating the astrologer to himself and to his patron through the acts of teaching and learning, he notes here that each of these scholars is related to the other through education: Barlaam teaches Paolo da Perugia and Leontius Pilatus, both of whom become in time Boccaccio's own teachers, first in Naples then in Florence, whereas Boccaccio's primary source for a Hellenic forma mentis is Theodontius, whom he knows from the works of Paolo da Perugia. Boccaccio is to some extent defending the mediation of knowledge through education, just as he calls for commentaries to the unknown ancient authors at the end of the chapter. These Greeks are also connected to the civic entity of Florence, which Boccaccio had invoked in the defenses of da Barberino and Dante, through the relationship between Leontius Pilatus and Boccaccio himself.

Although Boccaccio's actual knowledge of Greek was very limited, he did try to learn the language, succeeding much more than Petrarch, who claims to have abandoned the study of Greek in his youth. ${ }^{85}$ Boccaccio viewed these modern authorities on Greek culture as a window onto the past that had thus far been closed to the Latin West, much like he and Petrarch were shedding new light on the Roman heritage in their recovery of ancient texts. Petrarch, however, did not accept these men as authorities on ancient Greece and even his reception of the arch-poet Homer was tepid when compared to that of Boccaccio. ${ }^{86}$ Later on, in Chapter Seven, Boccaccio describes with enthusiasm and pride his public role in reintroducing the study of Greek and of Homer into the city of Florence and his private role in encouraging Leontius's Latin translations of Homer's two poems. Boccaccio declares in his defense of Greek poetry that he himself was the first to bring the study of Greek back to the Florentine Studium:

Fui equidem! Ipse insuper fui qui primus meis sumptibus Homeri libros et alios quosdam Grecos in Etruriam revocavi, ex qua multis ante seculis abierant non redituri. Nec in Etruriam tantum, sed in patriam deduxi. 
Ipse ego fui qui primus ex Latinis a Leontio in privato Yliadem audivi. Ipse insuper fui qui, ut legerentur publice Homeri libri operatus sum. Et, esto non satis plene perceperim, percepi tamen quantum potui.

[It was I, in fact! And I too was the first who, at my own expense, called back to Tuscany the writings of Homer and of other Greek authors, whence they had departed many centuries before, never meanwhile to return. And it was not to Tuscany only, but to my own city that I brought them. I, too, was the first to hear Leontius privately render the Iliad in Latin; and I it was who made arrangements for public readings from Homer. And though I did not understand Homer any too well, I got such knowledge of him as I could. $]^{87}$

The translation of Homer's poem, which also interested Petrarch, ${ }^{88}$ is only a part of Boccaccio's operation in bringing Greek back to Florence. Instead of monumentalizing himself as the ideal receptacle of ancient culture, Boccaccio stages himself as the prime mover in the rapprochement of Greek and Latin within the civic theater of Florence. As Boccaccio presents it, he and his contemporaries can come into contact with knowledge of the vanished ancient world that gave birth to Homer by creating links between themselves and modern Greeks (Barlaam and Leontius) and Italian Hellenophiles (Paolo da Perugia, source of Theodontius).

Boccaccio's enthusiasm is checked to some extent in his description of Leontius, who is the only example of a modern authority whose demeanor actually speaks against his trustworthiness. Boccaccio writes that he "aspectu horridus homo est, turpi facie, barba prolixa et capillicio nigro, et meditatione occupatus assidua, moribus incultus, nec satis urbanus homo [is a man of uncouth appearance, ugly features, long beard, and black hair, always taken with meditation, rough in manners, and not civilized enough]." ${ }^{89}$ Unlike the others, each models of prudence, Leontius's authority seems to be based solely on his knowledge of the Greek world. A Silenus figure whose inner worth is not reflected in an outer beauty, Leontius's uncouth aspect reveals his Greekness, his foreignness in relation to a refined Florentine aristocracy. From the point of view of Latinity, in fact, he is a barbarian: "esto in latinarum [licterarum] non satis adhuc 
instructus sit [In Latin he is not as yet learned enough]. ${ }^{90}$ It is in his very Latin barbarism, in fact, that Leontius's authority resides.

Boccaccio's description of the Calabrian Greek inverts the sense of Petrarch's words against Leontius in the last lines of a 1365 letter to Boccaccio (Seniles V, 3), in which Petrarch criticizes physicians for, among other things, insistently leaning on the authority of the Greeks. Petrarch's negative opinion of Leontius depends on the diatribe against the ostentation of Greek knowledge that is the pretense for the letter. ${ }^{91}$ Physicians, he says, will wait for you to die "cum tibinescio quibus Cois auctoribus Pergameisque et Arabibus, doctis forsitan sed nostrarum complexionum prorsus ignaris-poculum lethale porrexerint [after offering you a lethal drink based on some authority or other from Cos, Pergamum, and Arabia, learned perhaps but utterly ignorant of our constitutions]." 92 The physicians whom Petrarch counts among his friends, however, often quote Aristotle, Cicero, Seneca, and even Virgil..$^{93}$ In opposition to such good Latin doctors, modern physicians have become mere ventriloquists of Greek authorities that they cannot understand and that they use to stupefy their patients:

ut tamen cum his ipsis, siquis est aditus, in gratiam revertar neu semper contra hoc artificium genus loquar, grecis certe remediorum nominibus ac morborum prestare credentibus sunt soliti ut egrotent grece; prestarent saltem ut grece etiam curarentur!

[to come to terms even with these quacks-if it is possible-and not always to speak against this kind of technician, with Greek names of remedies and diseases they like to make those who believe them get sick in Greek. Let them at least make them get well in Greek too!].$^{94}$

The promises of physicians, he goes on to conclude, not only are subject to a Greek moral constitution and a temporal organization different from the Latin norm, but they seduce their patients through the exoticism of the unknown tongue:

Promittunt tamen eque omnes, ut ad rem redeam; promittunt, inquam, sed promissum impleturi, ut dicere solebat Augustus Caesar, ad Kalendas grecas, idest nunquam, siquidem et egrorum necessitas et 
fallentium promissio greca est et herbarum et frondium et radicum nomina balaustium, reubarbarum, calamentum. Nil non grece, quodque est molestius, arabice geritur, ut et mendacio longe petito plus fidei et remedio peregrino plus precii sit. Rursum illico ut admissi sunt, morbi nomen grecum dicunt aut, si opus est, faciunt: hec est, inquiunt, epilentia, hec apoplexis, hec erisipila: quis non tam sonoris nominibus delectetur et nosse cupiat quid dicatur grece quod latinus eger patitur, quamvis nec greca sint remedia nec latina?

[They all make the same promises; they make promises, I say, but they will fulfill their promises, as Augustus Caesar used to say, on the Greek kalendsthat is, never. In fact, the patients' need and the deceivers' promise are Greek, as are the names of their herbs and leaves and roots: balaustium, reubarbarum, calamentum. Everything is done in Greek, and what is even more troubling, in Arabic, so that the more far-fetched a lie, the more it is credited, and the more foreign a remedy, the more it costs; the minute they gain admission, they give the Greek name of the disease or, if necessary, invent one. This, they say, is epilepsia, this is apoplexia, this is erysipelas. Who would not be charmed by such sonorous names, and who would not like to know what disease that the Latin patient suffers is called in Greek, although there are neither Greek nor Latin remedies? ${ }^{95}$

Petrarch argues that that the cultural capital of Greek foreignness and novelty is based on a false cultivation of faith. The credit placed in these foreign authorities is only and literally payable in coin, not in the effective cure of the ill. Unlike Boccaccio, Petrarch is unwilling to risk a faith in the new authorities of his time. The entire letter, ostensibly about the "audacia et pomposo medicorum habitu [boldness and pompous routine of physicians], ${ }^{96}$ has attacked physicians for the novelty of their Hellenism as a way to preface the real target of his ire, Leontius Pilatus, the source of the influx of literary Greek into Florence. ${ }^{97}$ The Calabrian Greek, whom Petrarch says "thesalus dici malvult quam italicus [would rather be called Thessalian than 
Italian]," has fallen into disrepute because of his decision to abandon Florence for Byzantium and to leave imperfect his translations of Homer, on which Petrarch himself depended to complete his Latin library:

Qui tanto fastu, cum in omni fortuna turpi tum in paupertate turpissimo, delitias florentinas sprevit, tanto gemitu bizantinam ferat inopiam; denique, qui itala culta damnavit, senescat, per me licebit, in silvis hemoniis et grecis esca sit vermibus . . homo alioquin nostris studiis non ineptus, si tamen homo esset nec se beluam asperitate insigni et novitatis studio effecisset. Quam ob causam nescio, nisi vel nature durioris imperio coactus vel hoc calle fortassis, quod multos fecisse novimus, famam querens. Eat sane suosque sibi mores habeat, suam barbam, suum pallium, suam famem, metatque quod sevit, teratque quod messuit, edat denique quod intrivit.

[Let him who has scorned Florentine luxuries with so much conceit, which is ugly under any circumstances, but particularly when poor, now suffer the poverty of Byzantium with as much groaning; finally, let him who has condemned the fields of Italy grow old, with my permission, in the Thessalian forests, and be food for Greek worms . . . . This man would otherwise be no hindrance to our studies if he were a man and had not made himself a wild beast by his uncommon rudeness and passion for novelty - why, I do not know, unless his savage nature forced him or perhaps he seeks fame along this path, as we know many have done. Anyway, let him go and have his customs, his beard, his cloak, his hunger, and let him reap what he has sown, grind what he has harvested, and finally eat what he has ground. ${ }^{98}$

Whereas Boccaccio acknowledges the rude manners of his learned house guest as an authentic representation of Leontius's Greek origins, Petrarch condemns Leontius for choosing Greece over Italy, as if it were a choice between humanity and bestial barbarism. He fully links the aesthetic aspect of Leontius's appearance to the ethical 
qualities of the modern man, condemning his novitatis studium along with his asperitas insignis. Taken together with the preceding critique of the Hellenism of the physicians, Petrarch's invective against Leontius may be seen as an attack on Greek culture as a whole. Its implication is that Greek culture cannot provide succor for the ills of present-day Italy. Leontius's departure from Florence becomes the excuse for Petrarch's assertion of the cultural hegemony of Latin. ${ }^{99}$

The power of Greek literature, and specifically of Homer, to upset Petrarch's revision of cultural history through his restriction of the Latin canon, is indicated at the end of another letter from around the same time (Seniles V, 1). Having received from Boccaccio a full translation of Homer's Iliad along with only a portion of the Odyssey, Petrarch is disappointed to find out that Boccaccio has only sent him the part containing Odysseus's descent into the underworld:

Quod michi de Homero manu tua scriptum miseras, antequam Venetiis proficiscerer suscepi, ut fide atque indulgentia tua letus sic supervacuo mestior labore, quem tibi impositurus non fueram si scivissem quod nunc scio. Non enim nosse optabam quid apud graios inferos ageretur - apud latinos nosse quid agitur satis est, idque vel lectione vel auditu solo, utinam nec visu unquam nosse contigerit!-; sed volebam scire qualiter Homerus ipse, graius homo vel asiaticus et, quod miraculum auget, cecus quoque, solitudines italas descripsisset, vel Eoliam scilicet vel Avernum lacum montemque Circeum. Se quoniam ita tibi placuit ut michi, postea, totum opus illud eximium destinares, ibi forsan inveniam quod quero. Spem tamen hanc minuit quod scribis misisse te Yliadem totam, Odissee autem partem: in eo quidem libro est quod scire velim. Miror sane quid ita illam totam, huius partem miseris, sed fortasse integram non habebas; quicquid erit, videro dum me domum mea sors revexerit transcribique faciam et remittam tibi, quem tanta re caruisse pati nolim.

[Before I set out for Venice, I began reading what you sent me of Homer in your own handwriting. Delighted as I was by your faith and indulgence, I was 
all the sadder for the unnecessary labor that I would never have imposed on you had I known then what I know now. For I had no wish to know what went on in the Greeks' hell; it is enough to know what goes on in the Latin hell. Would that it befall me to know it only through reading or hearsay, and never by seeing it! But I did want to know how Homer, a Greek or an Asian, and-what makes it more miraculousblind too, described the solitary places of Italy, such as Aeolia, Lake Avernus, or the Mount of Circe; but since you have decided to earmark for me that entire incomparable work later, perhaps I shall find there what I am seeking. But my hope is weakened by your writing that you have sent all of the Iliad but only one part of the Odyssey. I wonder why you sent all of one and only a part of the other. Perhaps you did not have it in its entirety. Whatever the case, I shall see when my destiny brings me home, and I shall have it transcribed and returned to you, whom I could not bear to deprive of so great a treasure. $]^{100}$

There are many issues that this paragraph implicitly raises on the importance of Greek poetry for Petrarch and Boccaccio, ${ }^{101}$ but I will focus on one in particular: the notion of literary history that each gleans from Homer. Boccaccio, in his choice of works, sends a message to Petrarch about Homer's connection to Dante. Why, indeed, would Boccaccio send him the entire Iliad and only the nekuia of the Odyssey? It is clear that by the time of Leontius's departure from Florence in 1363, Boccaccio possessed the entire text of both of Leontius's Latin translations in a dual-language codex. ${ }^{102}$ The implicit answer to this question lies in the nature of the literary history that Boccaccio traces in the Genealogie. The descent into the underworld connects Homer with Virgil, then Virgil with Dante, in a genealogical line of descent by which the one builds off of the other, even across radical linguistic and cultural differences. Homer's Greek poetry can justify the authority of Dante's Florentine Commedia by displacing the centrality of the Latin Virgil. By inserting Dante's poem within a new literary history, Boccaccio uses Homer to justify not only the Commedia itself, but a new vernacular tradition. Although Petrarch had requested this part of the Odyssey in an earlier 
letter (Seniles III, 6), it is clear from his reaction that he was not interested in the nekuia itself, but in the Greek poet's descriptions of Italy, where presumably he would have found the font of Virgil's imitation of Homer. ${ }^{103}$ These missing parts of the Odyssey would have placed Petrarch in the line that leads from Homer through Virgil to a Latin modernity in series of competitions that culminate in Petrarch himself. ${ }^{104}$ Furthermore, Boccaccio seems to be denying Petrarch's connection to Odysseus by sending the entire Iliad instead, ${ }^{105}$ with which he signals both Petrarch's Africa, as an epic poem of war, and his political role in justifying the Visconti in Milan as modern martial heroes. ${ }^{106}$

By deferring to the authority of modern Greek scholars such as Barlaam, Paolo da Perugia, and Leontius Pilatus, Boccaccio is changing how the past is known and represented, but also how present and future generations may define themselves in relation to antiquity. In the penultimate example of a reliable modern source, Boccaccio defends his use of Paolo Geometra, whom he cites only once in the entire work, a Florentine astrologer who wrote a treatise on astronomy and natural and medicinal secrets. ${ }^{107}$ Boccaccio remembers this mathematician, geometer, and astrologer for his world-wide fame and for the wonder that he caused by demonstrating his knowledge of the stars with handmade instruments:

eo quod noverim nulli usquam alteri tempestate hac adeo sinum arismetricam, geometriam et astrologiam aperuisse omnem, uti huic aperuere, in tantum ut nil arbitrer apud illas illi fuisse incognitum; et, quod mirabile dictu est et visu longe magis, quicquid de syderibus aut celo loquitur, confestim propriis manibus instrumentis in hoc confectis, oculata fide demonstrat spectare volentibus. Nec est hic tantum patrie aut Ytalis notus, longe quidem studiorum suorum Parisius fama clarior est, quam apud suos sit, sic et apud Britannos Hyspanosque et Affros, quos penes hec in precio studia sunt. Equidem felix erat homo iste, si animo fuisset ardentior, aut liberaliori seculo natus.

[I am convinced that to him more than to any other man in our time the sciences of arithmetic, geometry, and astrology have opened and revealed their very 
depths; indeed, it seems as if no detail of them had escaped him. Wonderful as it sounds, more wonderful yet is it to see him give immediate ocular proof to anyone who wants to see, of every word he utters about the stars or heavens. This he does by means of instruments that he has made for the purpose with his own hands. He is known not only in his native city, nor only in Italy; the fame of his scholarship is far more illustrious in Paris than among his own people, as it is also among the Britons, the Spaniards, and particularly among Africans, who give these subjects special importance. Indeed he would have been happy, if he had had a more ardent spirit, or if he had been born into a more liberal age.] $]^{108}$

Like Andalò del Negro, Paolo Geometra redeems the modern sciences, or technical arts, by the seriousness of his study. By asserting the truth of the astrologer's claims to knowledge about the heavens and by drawing attention to the marvel caused by the astrologer's aesthetic display of proof, Boccaccio is responding to Petrarch's well-known misgivings about the uses of astrology in understanding human affairs.

In a 1363 letter to Boccaccio about the effects of the plague (Seniles III, 1), which had caused the death of many of his friends, ${ }^{109}$ Petrarch inveighs against astrologers and their science:

Fixum est enim, preteritorum atque presentium ignaris, ventura prenoscere, seu verius quasi precognita, prenunciare credentibus. Quorum iam non infidelitas solum atque impietas, sed ruditas intellectus, verique omnis incapacitas nota est his fidem habentium: contra quos veritas et ratio et experientia et non sancti tantum viri, sed philosophi etiam graves totis voluminibus attinguntur.

[Though ignorant of the past and the present, (the astrologers) are determined to foresee the future or, more precisely, to foretell it, as though foreknown, to those who believe. Not only infidelity and impiety, but also intellectual immaturity and incapacity for any truth is evident in those who put their faith in 
them; against them truth, reason, experience, and not only holy men but weighty philosophers do battle in entire volumes. $]^{110}$

Petrarch juxtaposes the knowledge of history, both ancient and modern, to the knowledge of the heavens, criticizing not only astrology but also those who value it as a form of knowledge. Petrarch focuses his critique of astrology on the claims of astrologers to predict the future, limiting the science to the knowledge of the stars-a standard distinction. By following this distinction, however, he implies that knowledge of the stars per se offers no insight into the affairs of human beings in history. In support of his view, he invokes "Ciceronis, . . . Ambrosii, atque Augustini operosissimos, validissimos tractatus, disputationesque longissimas [the most painstaking and powerful treatises, the lengthiest disputations by Cicero, Ambrose, and Augustine]" that speak against the science. ${ }^{111} \mathrm{He}$ laments, however, that astrologers would scorn his authorities:

an qui Spiritum sanctum spernunt, Spiritus sancti organum, sanctorum linguas et calamos non contemnent? Nec reverentius Isaiam audient dicentem: "Annuntiate que ventura sunt in futurum, et sciemus quia dii estis vos." Nam ut Novi Testamenti scriptores ignorantie, sic prophetas arguunt insanie et, ad summam, omnia, preter Ptholomeum egiptium ac Firmicum siculum, execrantur.

[Can those who scorn the Holy Spirit not despise the words and pens of saints, those instruments of the Holy Spirit, or listen more reverently to Isaiah saying: "Predict what is to come and we shall know that you are gods?" As they accuse of ignorance the writers of the New Testament, so do they accuse the prophets of madness. In sum, they curse everyone but Ptolemy the Egyptian and Firmicius the Sicilian.] ${ }^{112}$

According to Petrarch, the astrologers scorn the words and pens of true prophets, who are the instruments of the Holy Spirit (Spiritus sancti organa). Thus, when Boccaccio highlights the wonder that Paolo Geometra causes when he provides visible evidence of his knowledge with the instruments that he himself has made (propriis 
manibus instrumentis . . confectis), he is establishing the astrologer's authority in response to Petrarchan misgivings about modern forms of knowledge.

Although Boccaccio makes no claims for astrological prediction of historical events, the function of Paolo Geometra's instruments are similar to that of poetry in Boccaccio's eyes, since both work toward unveiling and imitating aesthetically the marvels of nature. ${ }^{113}$ For Boccaccio, the scientific instruments of Paolo Geometra unveil natural truths that inform the enterprise of the poet. When Petrarch denies the prophetic powers of astrologers, then, he is really disallowing the capacity of the technical art to inquire into the truth. By utilizing a standard distinction about the kinds of knowledge provided by "astrology" as a discipline, Petrarch suggests that inquiry into human nature and history-for him the realm of theological and poetic inquiry - cannot be informed by a science that merely traces the movements of the stars. Earlier in the letter, Petrarch had said that the astrologers who make claims to a nontechnical truth "mendaciorum tristium opifices respuendi eque commercio non literatorum modo sed bonorum omnium repellendi [ought to be spurned as fabricators of dismal lies and refused from exchange not only with scholars but with all good men]." 114 Petrarch depicts astrologers as infidels, who-like physicians-deserve no credit from good men or scholars. His use of a word such as commercium even evokes the mercantile terminology that underlies Boccaccio's gamble in placing his faith in new men and disciplines. Boccaccio goes against Petrarch's principle of exclusion to include not one, but two astrologers among the egregi viri of the trusted sources in his treatise.

To a certain extent, Paolo Geometra embodies aspects of the qualities that Boccaccio had praised in all of the previous men, such as his reputation and role as public intellectual, his connection to others through teaching and fame, his experiencebased authority, but he also surpasses them by the far-reaching extent of his fame. Like Andalò del Negro, he too is well known to King Hugh IV-“quem tibi, rex inclite, fama notissimum scio [I am sure, O illustrious King, that you know him well by reputation]"115_but with an even greater fame than that of the Genoese astrologer, Paolo is known in Paris, England, Spain, and Africa. With the exception of the last two locations, which must allude to the connection between astrology and Ptolemy and to the Arabic astrological tradition, ironically these are also the places where the 
fame of Boccaccio's final modern source, Francesco Petrarch, has reached:

Quem non dicam Ytali omnes, quorum singulare et perenne decus est, sed et Gallia omnis atque Germania, et remotissimus orbis angulus, Anglia Grecique plures poetam novere precipuum; nec dubito quin usque Cyprum et ad aures usque tue Sublimitatis nomen eius inclita fama detulerit.

[His great eminence as a poet has been recognized by-I will not say merely all Italians, whose glory is singular and eternal-but by all France, and Germany, and even that most remote little corner of the world, England, as well as by many Greeks. Nor do I doubt that his great fame has brought his name to Cyprus, and hence to the ears of your Highness. ${ }^{116}$

This sentence dramatically shows how Petrarch's fame enfolds the geographical distances of the known world in the adjacency of the words for England and Greece: Anglia Grecique. Like that of Paolo, Petrarch's fame reaches the ends of the earth: even the Cypriot king has heard his name. Petrarch's reputation in Greece undermines to a certain extent the exclusivity with which he publicly represented his Latinity. His name had reached Greece and Cyprus, not because the Greeks were Latinate, but-more likely-due to his friendship with men connected to the Greek world (such as Nicola Sigero, Barlaam, and even Leontius himself), who could act as cultural intermediaries and translators. ${ }^{117}$ True to Petrarch's representation of himself as a Roman poet on par with Virgil, his fame encompasses almost the entirety of the Roman Empire, linking Italy to Germany, France, England, and Greece.

Paolo, too, unites the Latin world of Italy with the scholastic communities of Paris and England and with the Arabic scientific traditions of Spain and Egypt, completing with Petrarch the geographical area of the Roman Empire. The geographical limits of these men's fame trace the intellectual boundaries of Boccaccio's cultural encyclopedia, yet they also indicate the geometrical center around which these boundaries are traced: Florence. Boccaccio describes both Paolo Geometra and Petrarch as having originated in Florence: the former is concivem meum (my fellow citizen), whereas the latter 
bears the same epithet as Dante, simply florentinum (Florentine). ${ }^{118}$ By locating Petrarch in Florence, Boccaccio not only redeems his teacher's refusal to return there as a university professor in 1351, but he also appropriates Petrarch's fame for the purposes of the Florentine republic. ${ }^{119}$ Boccaccio found more fruitful an open cultural program that offered a cosmopolitan view of culture from within a living political entity, whereas Petrarch sought to found his own program of cultural renewal on Roman authorities, whom he joined to his select few friends in a cosmopolitan republic of letters that rotated around Petrarch himself. ${ }^{120}$ Nevertheless, the principle of inclusion that Boccaccio puts forth here is capable of absorbing and assimilating two such diverse forms of culture as Petrarch's new Rome and Paolo Geometra's exotic and marvelous science.

In a subsequent reference to Petrarch's laureation, Petrarch's fame not only comes to designate a part of the geographical breadth of Boccaccio's cultural program, but it also becomes the rhetorical figure that bridges the historical gap between the ancient and the modern. Boccaccio calls attention to the fact that he is placing Petrarch among the moderns by mentioning that his teacher actually belongs among the ancients because of his successful laurel crowning:

nuper Rome ex senatus consulto, approbante Roberto, Ierusalem et Sycilie rege inclito, ab ipsis senatoribus laurea insignitum, inter veteres illustres viros, numerandum potius quam inter modernos.

[Recently at Rome, by vote of the senate and approval of the famous King Robert of Sicily and Jerusalem, he received the decoration of the laurel crown from the very hands of the senators. He really ought to be counted among the illustrious ancients, rather than among the moderns. $]^{121}$

Boccaccio begins his description of Petrarch's laureation with the temporal adverb nuper, pointing out the novelty of Petrarch's achievement. When he goes on to claim that Petrarch should really be considered an ancient, then, it is with no small amount of irony that he actually includes him among the moderns. Boccaccio unmasks Petrarch's modern stylistic reworking of Roman antiquity and rejects his fashioning of himself as an ancient Roman by making 
him a modern Florentine. Petrarch's authority as a citizen of Rome, acquired along with the laurel crown, is coopted to serve the civic life of Florence.

Boccaccio's employment of Petrarch's laurel ceremony is not entirely out of place, though it does invert Petrarch's sense of his own novelty. Petrarch's modern reenactment of the laurel coronation in the Collatio laureationis (1341) had in fact sought to elide the gap between modern and ancient Rome within the figure of the modern poet. ${ }^{122}$ The memory of the ancient city was evoked for the purposes of political and cultural justification. The key moment of Petrarch's reappropriation of Roman antiquity in the oration falls in his commemoration of the honor of the Republic, in which he recalls the past poets who had received the laurel prize and explains his decision to receive the crown in Rome and not at the Parisian studium. Comparing the presentem famam studii illius (present fame of that university) with the amor patriae that brought him to Rome, he cites Cicero in justification of his choice:

nec negaverim plurimum me in hanc sententiam impulisse affectum quemdam et reverentiam veterum poetarum, qui excellentibus ingeniis in hac eadem urbe floruerunt, hic vixerunt, hic denique sepulti sunt, ut enim prelcare Marcus Tullius secundo De legibus ait: "Ego tibi istam iustam causam puto cur huc libentius venias atque hunc locum diligas," et sequitur: "Movemur enim, nescio quo pacto, locis ipsis in quibus eorum quos diligimus aut admiramur assunt vestigia. Inde quidem ipse ille nostre Athene non tam operibus magnificis exquisitisque antiquorum artibus delectant, quam recordatione summorum virorum: ubi quisque habitare, ubi sedere, ubi disputare sit solitus, studioseque eorum sepulcra contemplor." Hec ille mihi autem, fateor, hec non ultima causa fuit Romam veniendi. Ceterum quecunque sit causa, adventum ipsum et huic urbi et illi de qua et universe ytalie ipsa saltem rei novitate non inglorium futurum esse confido.

[I was much moved also toward this decision by a certain affection and reverence for those ancient poets of excellent genius who flourished in this very 
city, who lived here, who are buried here-even as Cicero well says in the second book of his Laws: "I regard this as a sound reason for your coming here by preference and for your loving this place," and continuing: "Our emotions are somehow stirred in those places in which the feet of those whom we love and admire have trodden. Thence even Athens delights us not so much through its magnificent buildings and its exquisite works of ancient art as through the memory of its great men: it was here they dwelt, here they sat, here they engaged in their philosophical discussions. And with zeal I contemplate their tombs." This, I confess, was not the least of the causes for my coming to Rome. But whatever the cause, I trust that my coming, because of the novelty of the occasion if for no other reason, may serve to bring some glory to this city, to the city whence I come, and to all Italy.] ${ }^{123}$

Petrarch's novitas, or modernity, unlike that championed by Boccaccio, is founded upon the individual's memory of the dead, whom Petrarch does not so much resuscitate as replace. ${ }^{124}$ His modernity resides precisely in the act of remembering and revering the dead, in the contemplation of the tombs of great men. In this sense, his project of cultural renewal depends upon the death of antiquity. Although he evokes Rome in terms of memoria loci, the Rome that he recreates anew in the Collatio resides not in the reality of a geographical place, but in the act of commemoration itself, becoming instead a locus memoriae. The Collatio thus replaces both the Rome of the present day and that of antiquity with the phantasm of memory in the mind of Petrarch, which the laureation publicly authorizes him to monumentalize in his works. By inserting himself and his memory as a mediator between the two versions of the city, Petrarch takes on the old role of poet laureate within a new political theater, bringing glory to the present Rome and thereby to the entire peninsula, even to Florence. ${ }^{125} \mathrm{He}$ belongs neither to the Rome of his day nor to the Rome of Virgil, but to an ideal city that resides outside of time.

By evoking Petrarch as a Florentine who was recently crowned poet laureate, Boccaccio makes use of Petrarch's monumental laureation for the purposes of life. Taking literally Petrarch's hope to bring glory to his city of origin, Boccaccio connects Petrarch to his living 
contemporaries and disallows not only Petrarch's claims to uniqueness and exceptionality as a citizen-poet of Rome, but also his tenacious faith in the stability of Latinity. He inserts the Aretine poet and his new Rome into the same network of poets and storytellers whose work informs his inquiry in the Genealogie, relating the Petrarchan cultural project to a Greek poetic antiquity and a European scientific modernity. In this way, Boccaccio utilizes Petrarch's new Rome at the same time as he denies its self-sufficiency. In place of Petrarch's phantasmatic Rome, which never existed and will never exist except in the poet's memory and works, Boccaccio posits Florence as the actuated civic body that can propagate Petrarchan Latinity. Petrarch's laurel ceremony, together with Boccaccio's reappropriation of it within the economy of his defense of modernity, also redeems and enacts what had been denied to Dante as the poet laureate manqué. Boccaccio does not refuse Petrarch's model, founded upon the solid and fertile ground of memory, but by dismantling its exclusivity and including it within the Helleno-Florentine network of the Genealogie, he appropriates it to his own ends.

The defense of Greek poetry and the defense of modernity in the final book of the Genealogie are connected by Boccaccio's vision of culture as a process of relation and inclusion. Rather than founding a new Rome that defines itself in terms of the elimination and exclusion of otherness, Boccaccio opts for a vision of culture founded on the living world of becoming. By effectively displacing the authority of Petrarch's Roman auctores, Greek poetry justifies Boccaccio's project of cultural expansion, just as much as the modern scholars and poets, who provide a unique perspective on antiquity itself, allow for a realignment of ancient culture toward the present and future. By pointing out the necessity of modern sources for an authentic reconstruction of the past in a living present, by equalizing the modern and the ancient, and by showing how Latin learning could be improved by an inclusive attitude, Boccaccio anchors his ship and lays the foundations for the humanistic learning of the future. ${ }^{126} \mathrm{He}$ promotes an alternative iteration of the studia humanitatis that traces lines of continuity in the cracks of rupture between the ancient and modern worlds and that destabilizes previous notions of authority founded on the weight of a closed Latin canon. According to his vision, modern scientists and scholars are as valuable as the classical heritage and can even change the way that heritage is received; vernacular poets such as Dante and Latin poets like Petrarch can 
participate together alongside Ovid, Virgil, and Homer in a mythopoeic network of the human imagination that enlivens the political reality of the present and projects into the future.

\section{-Stanford University}

\section{NOTES}

Earlier versions of this essay were presented at the Center for Medieval and Renaissance Studies at Binghamton University in October 2011, the Renaissance Studies Program Lunch Lecture Series at Yale University in November 2011, and at the Division of Literatures, Cultures, and Languages at Stanford University in February 2012. I would like to thank the organizers and participants of those colloquia for their generosity and feedback, and in particular Marilynn Desmond, Olivia Holmes, and Dana Stewart for giving me the opportunity to present this idea for the first time at Binghamton and to revise it for Mediaevalia. I am especially grateful to the two anonymous readers for Mediaevalia for their useful critiques and to Angela Capodivacca, Sabrina Ferri, Giuseppe Mazzotta, and Andrea Nightingale for having read and commented on the essay at different stages in its development. It goes without saying that all of its limitations remain my own responsibility. Finally, I have benefited greatly from the collective insights of the students in my graduate seminar on politics and poetry at Yale, whom I would also like to thank.

1. Giovanni Boccaccio, Genealogie Deorum Gentilium, ed. Vittorio Zaccaria, in Tutte le opere di Giovanni Boccaccio, 10 vols., ed. Vittore Branca, vols. 7-8, 11-1813 (Milan: Mondadori, 1998), 15, Proem, 1 (8:1511), trans. Charles Osgood, Boccaccio on Poetry (Princeton: Princeton University Press, 1930; repr. New York: The Liberal Arts Press, 1956), 102, modified. For quotations from the Genealogie, I have used throughout Zaccaria's edition of the Latin text, with Osgood's English translations of the final two books and Jon Solomon's English translations of the first five books in Giovanni Boccaccio, Genealogy of the Pagan Gods, vol. 1, trans. Jon Solomon, I Tatti Renaissance Library 46 (Cambridge: Harvard University Press, 2011). References to the Genealogie are to Book, Chapter, Paragraph, followed by volume and page numbers for the Zaccaria volume in parentheses. Occasionally I have modified the English translations in order to communicate more fully the literal sense of individual words. When this is the case, I mention it in the notes. Unless otherwise noted, the translations are my own.

2. My use of the term network throughout this essay is inspired by readings in actor-network theory. Although mine is a misappropriation of that social theory of the sciences, I have found the theory useful to think about the genealogical structure of Boccaccio's work in a nonteleological fashion. That is, it has taught me to focus not on the point of origin nor on the point of arrival of his mythographical narratives, but on their interrelationship. Since these 
genealogical narratives tell not only the story of the interrelationship of the gods, but also that of the humans that created them, I have also found that Boccaccio's source material, that is, the literary history which he fashions in the Genealogie, may be viewed from the point of view of the network. In this regard, I have found particularly fruitful the following iterations of actor-network theory: Michel Serres, The Parasite, trans. Lawrence R. Schehr (Baltimore: Johns Hopkins University Press, 1982), esp. 224-34; Michel Serres with Bruno Latour, Conversations on Science, Culture, and Time, trans. Roxanne Lapidus (Ann Arbor: University of Michigan Press, 1995); Bruno Latour, We Have Never Been Modern, trans. Catherine Porter (Cambridge: Harvard University Press, 1993); Julian Yates, "What are 'Things' Saying in Renaissance Studies?," Literature Compass 3, no. 5 (2006): 992-1010; and Mario Biagioli, "Post-Disciplinary Liasons: Science Studies and the Humanities," Critical Inquiry 35 (2009): 816-33.

3. On the chronology of the composition of the mythographical books of the Genealogie and of the defenses of poetry and author, see Zaccaria, Nota al testo, in Boccaccio, Genealogie, 8:1587-1606 (8:1592-99). For his worries on the negative reception of the pagan material among Christian zealots, see also Boccaccio's 1372 epistle to Pietro da Monteforte (Epistola XX), in Boccaccio, Epistole, ed. Ginetta Auzzas, in Boccaccio, Tutte le opere, ed. Branca, vol. 5, part 1, 495-856 (Milan: Mondadori, 1992), 674-89.

4. Vittorio Zaccaria, Introduzione, in Boccaccio, Genealogie, 7:37. Boccaccio cites Homer in Greek more than forty times in the Genealogie using an interlinear translation provided by Leontius Pilatus, but he also cites Euripides's Hecuba and Lycophron's Alexandra. Osgood notices that Boccaccio's quotations of Greek are the first in "any work of modern Humanism" (192). See also Stephen Kolsky, Genealogy of Women: Studies in Boccaccio's De mulieribus claris (New York: Peter Lang, 2003), 39-40; Ernest H. Wilkins, The University of Chicago Manuscript of the Genealogia deorum gentilium of Boccaccio (Chicago: University of Chicago Press, 1927), 9-12; Cornelia C. Coulter, "Boccaccio's Aquaintance with Homer," Philological Quarterly 5 (1926): 44-53; and Oskar Hecker, Boccaccio Funde (Braunschweig: Westermann, 1901). For an extensive study on Boccaccio's and Petrarch's engagement with Greek culture through Leontius Pilatus, see Agostino Pertusi, Leonzio Pilato fra Petrarca e Boccaccio (Venezia: Istituto per la collaborazione culturale, 1964). More recently, see also the following essays in Quaderni Petrarcheschi 12-13, Petrarca e il mondo greco, vol. 1 (2002-3): Marianne Pade, "Leonzio Pilato e Boccaccio: le fonti del De montibus e la cultura greco-latina di Leonzio," 257-76; and Dieter Harlfinger and Marwan Rashed, "Leonzio Pilato fra aristotelismo bizantino e scolastica latina. Due nuovi testimoni postillati," 277-94. The second volume of the double issue is a study and edition of Leontius's translation of Euripides's Hecuba: Antonio Rollo, Leonzio lettore dell'Ecuba nella Firenze di Boccaccio, in Studi Petrarcheschi 12-13, Petrarca e il mondo greco, vol. 2 (2002-3). For an interpretative account of Boccaccio's and Petrarch's encounter with Pilatus and their respective uses of his translation, see Marilynn Desmond "On Not Knowing Greek: Leonzio Pilatus's Rendition of the Iliad and the Translatio of Mediterranean 
Identities," in Rethinking Medieval Translation: Ethics, Politics, Theory, ed. Emma Campbell and Robert Mills (Cambridge: D. S. Brewer, 2012), 21-40, which I was able to consult only at the copyediting stage. See also Pier Giorgio Ricci, "La prima cattedra di greco in Firenze," Rinascimento 3 (1952): 159-65, in which Ricci establishes that Leontius not only read Homer, but also taught the Greek language to a limited number of students. For Boccaccio's early ideas on Homer, see Manlio Pastore Stocchi, "Il primo Omero di Boccaccio," Studi sul Boccaccio V (1968): 99-122. For Boccaccio's engagement with the Greek patristics, see Susanna Barsella, "Boccaccio and Humanism: A New Patristic Source of Proemio 14 and the Pestilence. Basil the Great's Homily on Psalm 1," Studi sul Boccaccio 32 (2004): 59-79. For a postcolonialist reading of Boccaccio's philhellenism in the Decameron, see Teresa Kennedy, "Boccaccio's Greek Philology: A Rediscovered Country," in Through a Classical Eye: Transcultural and Transhistorical Visions in Medieval English, Italian, and Latin Literature in Honor of Winthrop Wetherbee, ed. Andrew Galloway and R. F. Yager (Toronto: University of Toronto Press, 2009), 165-88. As my colleague Millicent Marcus has pointed out to me, more than in any other story of the Decameron, it is possible to see how the reconciliation of Greek thought with Roman culture is dramatized in the tale of Sofronia, Gisippo, and Tito Quinzio Fulvo (X, 8).

5. Boccaccio's knowledge of the Greek language was limited, but the spirit with which he approached both the language and culture of Greece was pioneering. Coulter, following Hecker, notices that Boccaccio's "autograph copy of the Genealogia Deorum shows omissions and transpositions of letters which would have been quite impossible to anyone who had even an elementary knowledge of individual Greek words, and which indicate that he must have followed the text of his Greek manuscript blindly, with only the most general notion of its meaning" (51-52). She goes on to note, however, that "slight as his knowledge was, it gave him a first-hand contact with Homer as no man in Western Europe had had for centuries. One who made this contact through the medium of Pilato's execrable Latin could hardly be expected to appreciate the dignity and beauty of Homer's style; but at least Boccaccio had mastered the subject-matter of the poems and had the details well enough in hand so that he could quote a line or paraphrase a longer passage to prove his point; and his vivid retelling of certain stories proves that he had caught something of the spirit of the Greek" (52-53). Pertusi expresses a similar sentiment years later. If modern scholars hold Boccaccio to the kind of philological rigor of contemporary Hellenists, he is sure to disappoint. If, however, his effort is gauged according to its historical novelty, then he shows himself to be very innovative. Giannozzo Manetti, who studied Greek with Manuel Chrysoloras in the generation after Boccaccio, looked to Boccaccio as the pioneer in bringing Greek back to Florence. After a long aside on the study of Greek letters in his own age, Manetti notes: "Sed quorsum haec tam multa de litteris graecis, dicet quispiam? Quorsum? Ut totum hoc quicquid apud nos Graecorum est Boccaccio nostro feratur acceptum, qui primus praeceptorem et libros graecos, a nobis per longa terrarum marisque spatia distantes, propriis sumptibus in Etruriam reduxit [But someone might ask: why say all this about Greek letters? What is your point? My point 
is to show that we owe all our knowledge of the Greeks to our Boccaccio, who first brought back to Tuscany at his own expense a teacher and Greek books which had previously lain far away from us, over land and sea]," Manetti, Vita Ioannis Boccacii, in Biographical Writings, ed. and trans. Stefano U. Baldassarri and Rolf Bagemihl, I Tatti Renaissance Library 9, 86-105 (Cambridge: Harvard University Press, 2003), 96-97. Manetti goes on to note in his comparison of the three crowns that "Ceterum Boccaccio ita paene in omnibus prestat ut in paucis admodum ac levibus quibusdam, in graecarum scilicet litterarum cognitione, qua Dantes omnino caruit, et in materna ac soluta oratione qua pauca scripsit, sibi cedere videatur. In quibus duobus dumtaxat etiam Petrarcham excelluit, cum ab eo tamquam a praeceptore suo in ceteris omnibus vinceretur [Dante is superior to Boccaccio in almost everything, except for a few things of lesser importance, such as the knowledge of Greek letters, which Dante lacked completely, and the writing of prose works in the vernacular, which he did not practice often. These two are also the only things in which Boccaccio exceeded Petrarca, whereas in everything else he was surpassed by him, as a student by his teacher]." Ibid., 105-6.

6. As I will go on to explain and explore in detail in this essay, I understand the term modernity to denote a self-consciousness of one's own novelty, which is often represented in relation to antiquity. Modernity, etymologically connected to the new, is a historically relative term.

7. On Petrarch's empire of culture, see Giuseppe Mazzotta, The Worlds of Petrarch, Duke Monographs in Medieval and Renaissance Studies 14 (Durham: Duke University Press, 1993), esp. 102-28. See also Ronald Witt's comprehensive treatment of the Latin Petrarch in In the Footsteps of the Ancients: The Origins of Humanism from Lovato to Bruni (Leiden: Brill, 2000), 230-91. See Christopher S. Celenza, "Petrarch, Latin, and Italian Renaissance Latinity," Journal of Medieval and Early Modern Studies 35, no. 3 (Fall 2005): 509-36, for a discussion of Petrarch's Latinity between the medieval and Renaissance periods. For Petrarch's resistence to certain forms of modernity, or cultural novelty, such as scientific developments in the technical arts, see Francesco Bausi, "Petrarca antimoderno," in Bausi, Petrarca antimoderno (Florence: Franco Cesati, 2008), 193-224.

8. On the Boccaccian turn to Latinity upon meeting Petrarch, see Giuseppe Billanovich, Petrarca letterato: 1. Lo scrittoio di Petrarca (Rome: Edizioni di storia e letteratura, 1947), 104-6. See also how it was inserted in the prototypical biographical narrative in Vittore Branca, Giovanni Boccaccio: Profilo biografico (Florence: Sansoni, 1975; repr. 1997), 91. To a certain extent, however, the narrative of a conversion to Latin is already a theme in the correspondence between Boccaccio and Petrarch. See Petrarch's Seniles V, 2 and Eclogue XV of Boccaccio's Buccolicum Carmen ("Phylostropos"). There is the sense that Petrarch is trying to fashion Boccaccio just as much as he is himself, and that Boccaccio is resisting such a revision of his poetic self precisely in his most Petrarchan works. 
9. This is a critical commonplace about Petrarch that begins perhaps with Jacob Burckhardt's monumental 1860 study, The Civilization of the Renaissance in Italy. Although the notion of Petrarch as a modern intellectual remains, many scholars have since questioned and qualified this critical stereotype. See, for example, Albert Ascoli, "Petrarch's Middle Age: Memory, Imagination, History, and the Ascent of Mount Ventoux," Stanford Italian Review 10, no. 1 (1991): 5-43, Mazzotta, The Worlds of Petrarch, and Witt, In the Footsteps of the Ancients, 231-91.

10. On Petrarch's role in the Renaissance development of literary authority through imitation see Thomas M. Greene, The Light in Troy: Imitation and Discovery in Renaissance Poetry (New Haven: Yale University Press, 1982), 81-103, and Martin L. McLaughlin, Literary Imitation in the Italian Renaissance: The Theory and Practice of Literary Imitation in Italy from Dante to Bembo (Oxford: Clarendon Press, 1995), esp. 22-48.

11. Boccaccio's self-consciousness of the gap between the ancient and modern worlds and of the instability of his own age are clear from the first proem to the first book of the Genealogie. See in particular, Genealogie I, Proem 1, 26-32. See also Mazzotta, "Boccaccio: Mythographer of the City," in Interpretation and Allegory: Antiquity to the Modern Period, ed. Jon Whitman (Leiden: Brill, 2000), 349-64 (357-58), where he notes in passing that "Boccaccio's elegiac motif about time's sovereignity over human achievements expands into a reflection both on the divisive nature of all interpretation and on the political disintegration of Latinity" (357).

12. My use of the terms monumental, critical, and historicization will become clear in my discussion of the texts, from which they are derived. They are associated, respectively, with memory, genealogical inquiry and reconstruction, and historical contextualization. It is worth noting the similarity of these terms of inquiry with those used by Friedrich Nietzsche in "On the Uses and Disadvantages of History for Life," the second of the Untimely Meditations, ed. Daniel Breazeale, trans. R.J. Hollingdale (Cambridge: Cambridge University Press, 1997), 57-123. Although the terms as I employ them do not completely coincide with those of Nietzsche, his reflections on history are useful for understanding the broader implications of the differences between Petrarch's and Boccaccio's uses of the past for the purposes of the present. I am indebted to Andrea Nightingale for directing me to Nietzsche.

13. The entire passage is written in a tone of feigned modesty so that Boccaccio may distance his method from that of Petrarch: "Ast ego quid? Brevis sum homuncio, nulle michi vires, ingenium tardum et fluxa memoria; et tu meis humeris, non dicam celum, quod illi tulere, quin imo et terram super addere cupis et maria, ac etiam celicolas ipsos, et cum eis sustentatores egregios. Nil aliud hoc est nisi velle ut pondere premar et peream. Verum si tantum regi hoc erat animo, erat onus aptum, si inter mortales ullus est tanto labori sufficiens, viribus preclarissimi viri Francisci Petrarce, cuius ego iam diu auditor sum. Homo quippe est celesti ingenio preditus et perenni memoria, ac etiam facundia admirabili 
[But what about me? I am a little man, absent of strength, with a late-coming talent and a fluid memory. And upon my shoulders you want to add, not the heavens they (Atlas and Alcides) bore, but both the earth and the seas, and the heavenly dwellers themselves along with their distinguished companions. This is to wish nothing upon me other than that I be crushed by their weight and perish. If this was what was in the king's mind, the burden was fitting-if there is any mortal prepared for such a task-for the abilities of the famous Francesco Petrarch, whose disciple I have been for a long time now. This man is indeed endowed with a celestial talent and an eternal memory, as well as admirable eloquence]," Boccaccio, Genealogie I, Proem 1, 20-21 (7:50-52); Boccaccio, Genealogy, trans. Solomon 11, modified. This is not the first time that Boccaccio describes Petrarch's memoria and ingenium in this fashion. See his $D e$ Vita et Moribus Domini Francisci Petracchi, 23-24, in Boccaccio, Vite, ed. Renata Fabbri, in Tutte le opere, vol. 5, part 2, 899-911 (Milan: Mondadori, 1992), 908. It is worth noting that Boccaccio also defines the ingenium of women as tardum in the De Mulieribus Claris (Proem, 4), ed. Vittorio Zaccaria, in Tutte le opere, vol. 10 (Milan: Mondadori, 1967), 25.

14. This would not be the first time that Boccaccio would challenge Petrarch's public persona. In his tenth epistle, Ut huic epistole, written as a critique of Petrarch's choice to take up residence in Milan, Boccaccio ironically and playfully divides Petrarch into two selves, one public and one private, each of whom contradicts the other. For the text of the letter, see Boccaccio, Epistole, ed. Auzzas, 574-83. On Boccaccio's playful irreverence for his friend in this letter, see Jason Houston, "Boccaccio at Play in Petrarch's Pastoral World," MLN 127, no. 1 Italian issue supplement (January 2012): S47-S53. Boccaccio is fully aware of the contradictions and complexities of Petrarch's representation of himself, but it seems that Boccaccio is more willing to confront the instability of his age and the ruptures between past and present in a more open, public fashion.

15. Boccaccio's political manipulation of literary culture for the city of Florence, especially his refashioning and repatriation of Dante as a Florentine poet, has recently been explored in Jason Houston, Buliding a Monument to Dante: Boccaccio as Dantista. Houston also finds Boccaccio's primary difference of opinion on culture with Petrarch to be of a political nature. Specifically regarding the Genealogie, Mazzotta has argued that Boccaccio's treatise engages with the political problems of fourteenth-century Florence as it "traces the routes of the imagination as the means of countering the broken history of the present," in "Boccaccio: The Mythographer of the City," 364.

16. Vittore Branca's fundamental work on Boccaccio's medieval ethos, in Boccaccio medievale (Florence: Sansoni, 1956; repr. 1996), has, to a certain extent, led to the limited recognition of Boccaccio as humanist thinker. Branca does note, however, certain presentimenti umanistici in Boccacio's oeuvre (191-298).

17. The manner in which Boccaccio constructs the authority of modern writers in the Genealogie is one of the primary reasons the treatise has been long 
considered pejoratively as a medieval summa that lacks the historical sophistication of a modern humanist work. If it were modern, scholars such as Jean Seznec argue, it would not place medieval mythographers such as Alberic of London (the Third Vatican Mythographer) or the mysterious Thedontius on the same level as Cicero, Virgil, Horace, Ovid, and the other Roman auctores whose works he had at his disposition. See Jean Seznec, The Survival of the Pagan Gods: The Mythological Tradition and Its Place in Renaissance Humanism and Art, trans. Barbara F. Sessions, Bollingen Series 38 (Princeton: Princeton University Press, 1981), 220-24. See also Thomas Hyde, "Boccaccio: The Genealogies of Myth,” PMLA 100, no. 5 (Oct. 1985): 737-45, in which Boccaccio's attitude toward authority is redeemed as modern, inasmuch as modernity is irreverent and "illegitimate" (744).

18. Boccaccio writes, "Mare magnum et dissuetum navigiis intraturus novumque sumpturus iter, ratus sum prospectandum fore solerter quo ex litore cymbe proresia solvenda sint . . . Conveneram igitur mecum omnes animi vires et e sublimi mentis speculo omnem fere orbis intuebar ambitum [About to enter the great unknown sea and take up a new path, I thought that I should observe carefully from which shore the prows of my boat should be loosed ... I had therefore called to myself all the powers of my mind and from my mind's eye I imagined almost the entire circuit of the world]," Genealogie, 1, Proem 2, 1-2 (7:64). This is my own translation, but cf. Boccaccio, Genealogy, trans. Solomon, 1:25.

19. See Cicero, De Natura Deorum I, 25 for Thales, I, 26 for Anaximenes, I, 39-40 for Chrysippus, and I, 27 for Alcmeon. The first two names are also transmitted by Augustine in the De Civitate Dei Contra Paganos VIII, 2.

20. The term gravitas was synonymous with auctoritas in Boccaccio's sources. See Pliny the Younger, Epistole II, 13, 4, where the term is used synonymously with sanctitas and auctoritas. On the term gravitas and its relation to auctoritas in the Roman world, see Karl Galinsky, Augustan Culture: An Interpretative Introduction (Princeton: Princeton University Press, 1996), 166; on the term and its relation to authority (auctoritas) and dignity (dignitas) see Jean Philippe Lévy, "Dignitas, Gravitas, Auctoritas Testium," in Studi in onore di Biondo Biondi, 4 vols. (Milan: Giuffrè, 1965), 2:27-94. On the term's meaning in the Middle Ages, see Jacques Le Goff, History and Memory, trans. Steven Rendall and Elizabeth Claman (New York: Columbia University Press, 1992), in which he sweepingly declares that "the term 'antiquity' (antiquitas) is synonymous with authority (auctoritas), value (gravitas) and majesty (majestas)" (12).

21. For Macrobius's centrality to medieval understandings of antiquity, see Ernst Robert Curtius, European Literature and the Latin Middle Ages, trans. Willard R. Trask, Bollingen Series 36 (Princeton: Princeton University Press, 1953; repr. 1990), 443-45. 
22. After Ovid, Theodontius is the second most cited author in the Genealogie. His historical identity has never been resolved and his works have never been identified, except by indirect conjecture. He is mentioned only in the Fons memorabilium universi by Domenico Bandini da Arezzo as "Theodontius Campanus diligens investigator poetici figmenti [Theodontius of Campania, a diligent investigator of poetic fictions]," qtd. in Remigio Sabbadini, "Spigolature latine," Studi Italiani di Filologia Classica 5 (1897): 369-93 (377). On the question of Theodontius's identity, see the classical treatment by Attilio Hortis, Studj sulle opere latine del Boccaccio (Trieste: Libreria Julius Dase Editrice, 1879), 464-68. More recently, see Pastore Stocchi, "Da Crisippo al Boccaccio," in Tradizione classica e letteratura umanistica. Per Alessandro Perosa, 2 vols., ed. Roberto Cardini, Eugenio Garin, Lucia Cesarini Martinelli, and Giovanni Pascucci (Rome: Bulzoni, 1985), 1:139-58 and Pastore Stocchi, "Teodonzio, Pronapide e Boccaccio," Quaderni Petrarcheschi 12-13 (2002-03): 187-211. On the possibility that Boccaccio and an anonymous mythographer of the twelfth century shared Theodontius as a source, see Judson B. Allen, "An Anonymous Twelfth-Century de Natura Deorum in the Bodleian Library," Traditio 26 (1970): 352-64 and Virginia Brown, "An Edition of an Anonymous Twelfth-Century Liber de Natura Deorum," Medieval Studies 34 (1972): 1-70. On Paolo da Perugia, Boccaccio's source for Theodontius, see Teresa Hankey, "Un nuovo codice delle 'Genealogie deorum' di Paolo da Perugia," Studi sul Boccaccio 18 (1989): 65-162. Although I have not been able to consult it in the preparation of this essay, the most recent treatment of the subject is Maria Paola Funaioli, "Teodonzio: Storia e filologia di un personaggio," Intersezioni 31, no. 2 (2011): 207-18. Theodontius, like the other philosophers in this imaginary series of interviews, is a rhetorical embodiment of a textual source. Barring the discovery of a Theodontian manuscript linked to Boccaccio, it is unlikely that the enigma will be resolved. It is more fruitful, then, to see how Boccaccio employs Theodontius as a source throughout the Genealogie and how he uses the modern man to construct his own authoritative stance.

23. Cf. Hyde, "Boccaccio," 744.

24. Boccaccio's understanding of Greek religion was limited to his few sources on the matter. His discussions of the Greek thinkers that deal with the gods are only part and parcel of his views on Greek religion. His understanding of Greek ideas on cosmogony is linked to twelfth-century Neo-Platonic interpretations of the Timaeus, such as Bernardus Silvestris's Cosmographia. On his development of these notions in the first book of the Genealogie, see David Lummus, "Boccaccio's Poetic Anthropology: Allegories of History in the Genealogie Deorum Gentilium Libri," Speculum 87, no. 3 (July 2012): 724-65.

25. See Boccaccio, Vite di Dante, ed. Pier Giorgio Ricci (Milan: Mondadori, 1974; repr. 2002), 39 (par. 144-45).

26. Boccaccio, Genealogie I, proem 2, 5 (7:64); Boccaccio, Genealogy, trans. Solomon, 27. 
27. Boccaccio, Genealogie I, proem 2, 6 (7:66); Boccaccio, Genealogy, trans. Solomon, 27.

28. Boccaccio Genealogie I, proem 2, 8 (7:66); Boccaccio, Genealogy, trans. Solomon, 27.

29. Boccaccio Genealogie I, proem 2, 10 (7:66); Boccaccio, Genealogy, trans. Solomon, 29.

30. Boccaccio, Genealogie I, proem 2, 9 (7:66); Boccaccio, Genealogy, trans. Solomon, 29, modified.

31. Of course, there was no other way to know the Greeks in the Western Middle Ages except through Roman sources. Boccaccio is presenting an alternative in this mise en scène.

32. Boccaccio, Genealogie I, proem 2, 10 (7:66); Boccaccio, Genealogy, trans. Solomon, 29, modified.

33. Cf. Mazzotta, "Boccaccio,” 356.

34. See Lummus, "Boccaccio's Poetic Anthropology," 734-38, for an interpretation of Boccaccio's interrogation of the Greek philosophers and of the importance of Theodontius's "anthropological" point of view in Books One and Two of the treatise.

35. On the notion of authority and authorship in the Middle Ages see Alastair Minnis, Medieval Theory of Authorship: Scholastic Literary Attitudes in the Later Middle Ages, 2nd ed. (Philadelphia: University of Pennsylvania Press, 1988; repr. 2009). On auctoritas in Dante's oeuvre see Alberti Russell Ascoli, Dante and the Making of a Modern Author (Cambridge: Cambridge University Press, 2008). On the rhetorical tradition and notions of imitation and translation, see Rita Copeland, Rhetoric, Hermeneutics, and Translation in the Middle Ages: Academic Traditions and Vernacular Texts (Cambridge: Cambridge University Press, 1991). On the development of the notion of literary authority and imitation in the Renaissance see Greene, The Light in Troy, esp. 81-103 on Petrarch, and McLaughlin, Literary Imitation in the Italian Renaissance, esp. 22-48 on Petrarch. On Petrarch's notion of self and authority as essentially medieval, see Timothy J. Reiss, Mirages of the Selfe: Patterns of Personhood in Ancient and Early Modern Europe (Stanford: Stanford University Press, 2003), 308-12.

36. Linked to the medieval notion of the translatio studiorum, Boccaccio's understanding of the development and transmission of culture from East to West is more nuanced. Instead of merely reappropriating ancient culture regardless of the change in historical context, Boccaccio traces the terms according to which culture changes across time and space. Thus, instead of translatio studiorum, perhaps the term transmutatio fabularum would be more appropriate to describe the way he understands the transmission of culture in the Genealogie, which engages intensely with Ovid and resembles structurally the fifteen books of the Metamorphoses. 
37. See Lummus, "Boccaccio's Three Venuses: On the Convergence of Celestial and Transgressive Love in the Genealogie Deorum Gentilium," Medievalia et Humanistica 37 (2011): $65-88$, where I address this process of poetic transmutatio in a reading of the threefold figure of Venus in the Genealogie and the implications of this process for understanding the role of Venusian women in the Decameron.

38. Boccaccio, Genealogie XV, Conclusio, 3 (8:1582), trans. Osgood, Boccaccio, 141-42. See also Boccaccio, Genealogie XV, 12, 2, (8:1572), where he writes "non enim puero aut inerti vulgo scribimus, quin imo, ut alias dictum est, doctissimo regi et provectis hominibus [for my audience is neither children nor the lazy rabble, but, as I say, a most learned King and men of higher studies]," trans. Osgood, Boccaccio, 136.

39. Boccaccio, Genealogie XV, 7, 1 (8:1540), trans. Osgood, Boccaccio, 118.

40. Boccaccio, Genealogie XV, 7, 4 (8:1542), trans. Osgood, Boccaccio, 119, modified.

41. Francesco Petrarch, Seniles XII, 2, 70-71 (809-32) in Petrarch, Lettres de la vieillesse, 5 vols., ed. Elvira Nota (Paris: Les Belles Lettres, 2002-) [vol. 5 forthcoming], 4:95-97; Petrarch, Letters of Old Age, 2 vols., trans. Aldo S. Bernardo, Saul Levin, and Reta A. Bernard (Baltimore: The Johns Hopkins University Press, 1992; repr. New York: Italica Press, 2005), 2:472. All quotations from the Seniles refer to book, letter, paragraph, with the line numbers between parentheses. I have used the French/Latin edition prepared by Nota and the Bernardo English translation throughout, which I have occasionally modified for clarity. Page numbers for both editions are noted as well. Italics have been added for emphasis. Cf. Timothy Reiss, Mirages of the Selfe, 316-17.

42. The pretense for this letter is a critique of physicians, who, Petrarch says, only speak of Greek and Arabic authorities. He disposes of Greek authority by claiming that the Romans had conquered them in everything that they produced. The superiority of ancient Romans over the Greeks becomes, for Petrarch, the justification for considering the Italic minds of modernity as superior to Greek and Arabic sources of scientific knowledge. Petrarch's lack of consideration for the Greeks in favor of Romanity is not a product of his old age, but rather goes back to the 1330s. For example, in a letter to Giovanni Colonna about his 1333 trip to Aix-la-Chapelle, he wrote "Quodsi gratias agebat Plato diis, ut verbo eius utar, immortalibus, inter multa, quod grecum eum et non alienigenam edidissent, quid nos prohibit pro eodem quoque gratias agere ortusque nostri Deum auctorem recognoscere? Nisi forte nobilius est grecum nasci, quam italicum; quod quisquis dixerit, dicat idem et servum nobiliorem esse quam dominum. Atqui nullus hoc greculus, quantumlibet procax impudensque, dicere audebit . . . . Credo neminem negaturum aliquando clarius italicum esse quam grecum [And if Plato expressed his gratitude to what he called his immortal gods, among other things, for having been raised in Greece and not in another foreign land, what prevents us from expressing the same gratitude and recognizing our God as the author of our birthright? Unless, of course, it is more noble to be born 
a Greek than Italian; but whoever says this would also say that a slave is more noble than a master. But no ordinary Greek would dare say this, however great, impudent and imprudent he might be ... I I believe that no one would deny that it is considerably more noble to be Italian than Greek]," Familiares I, 4, 2 (10-17) and 3 (28-29), in Le Familiari, 4 vols., ed. Vittorio Rossi and Umberto Bosco (Florence: Sansoni, 1938-42), 1:24-25; Letters on Familiar Matters, 3 vols., trans. Aldo S. Bernardo (Baltimore: The Johns Hopkins University Press, 1975-85; repr. New York: Italica Press, 2005), 1:25. All quotations from the Familiares refer to book, letter, paragraph, with the line numbers between parentheses. I have used the Rossi/Bosco Latin edition throughout and the Bernardo English translation, which I have occasionally modified for clarity. Page numbers for the Latin and English editions are noted as well. For a survey of Petrarch's thought on the East, see Nancy Bisaha, "Petrarch's Vision of the Muslim and Byzantine East," Speculum 76, no. 2 (April 2001): 284-314. See also Roberto Weiss, "Petrarca e il mondo greco," in Medieval and Humanist Greek. Collected Essays (Padua: Antenore, 1977), 166-92. Petrarch's engagement with the "Greek World" was also the subject of a 2001 conference, the proceedings of which were edited by Michele Feo, Vincenzo Fera, Paola Megna, and Antonio Rollo and published in Quaderni Petrarcheschi 12-13, Petrarca e il mondo greco, vol. 1 (2002-3). In addition to the articles from this volume on Leontius and Boccaccio cited above, those on Petrarch especially useful in the context of the present essay are: Vincenzo Fera, "Petrarca lettore dell'Iliade,' 141-54; Filippomaria Pontani, "L'Odissea di Petrarca e gli scoli di Leonzio," 295-328; James Hankins, "Greek Studies in Italy: from Petrarch to Bruni," 329-40; and Anna Pontani, "Il mondo greco di Petrarca: considerazioni e prospettive," 341-50.

43. For an overview of Petrarch's style of imitation and its importance in the construction of the modern self, see Greene, Light in Troy, 93-100. For Petrarch's own discussions of imitative theory, see his Familiares I, 8, XXII, 2, and XXIII, 19, the last two of which Greene discusses in depth.

44. For the dating of the correspondence between Boccaccio and Petrarch, I have relied on Gabriella Albanese, "La corrispondenza fra Petrarca e Boccaccio," in Motivi e forme delle Familiari di Francesco Petrarca, ed. Claudia Berra (Milan: Cisalpino, 2003), 39-98. Albanese revises and corrects the table constructed by Ernest H. Wilkins in "A Survey of the Correspondence between Petrarch and Boccaccio," Italia medioevale e umanistica VI (1963): 179-84.

45. Petrarch, Familiares XXII, 2, 27 (174-83) in Petrarch, Le familiari, ed. Rossi and Bosco, 4:109; Petrarch, Letters on Familiar Matters, trans. Bernardo, 3:215.

46. On the modernity of Petrarch's excessive dependence on and creative engagement with Virgil in the Africa, see Jeffrey Schnapp, "Petrarch's New Antiquity," in Zeit und Text: Philosophische, kulturanthropologische, literarhistorische, und linguistische Beiträge, ed. Andreas Kablitz, Wulf Österreicher, and Rainer Warning (Munich: Fink Verlag, 2003), 236-45. See also Simone Marchesi, "Petrarch's Philological Epic (Africa)," in Petrarch: A Critical Guide to the Complete Works, ed. 
Victoria Kirkham and Armando Maggi (Chicago: Chicago University Press, 2006), in which he discusses not only how Petrarch reworked classical material, but how he engaged with Dante's Commedia. On Petrarch's borrowings in the Buccolicum Carmen, both from Virgil and from Ovid, refer to the above-cited letter, Familiares XXII, 2.

47. Boccaccio, Genealogie XV, 7, 7 (8:1544), trans. Osgood, Boccaccio, 121, modified.

48. Usually translated in English as "envy," the Ovidian term livor expresses a complex sentiment of hatred and spite that derived from envy. Petrarch, like Ovid, uses the term to express the sentiment of others in the light of his own literary fame. Boccaccio, however, uses the term to express the cause of the obfuscated judgment of history among his contemporaries, connecting it to the loss of freedom. Cf. Boccaccio, Genealogogie XIV, 1, 4 (8:1360). In this use, he may be following Tacitus, who writes in his Historiae: "nam post conditam urbem octingentos et viginti prioris aevi annos multi auctores rettulerunt, dum res populi Romani memorabantur pari eloquentia ac libertate: postquam bellatum apud Actium atque omnem potentiam ad unum conferri pacis interfuit, magna illa ingenia cessere; simul veritas pluribus modis infracta, primum inscitia rei publicae ut alienae, mox libidine adsentandi aut rursus odio adversus dominantis: ita neutris cura posteritatis inter infensos vel obnoxios. sed ambitionem scriptoris facile averseris, obtrectatio et livor pronis auribus accipiuntur; quippe adulationi foedum crimen servitutis, malignitati falsa species libertatis inest [Of the former period, the 820 years dating from the founding of the city, many authors have treated; and while they had to record the transactions of the Roman people, they wrote with equal eloquence and freedom. After the conflict at Actium, and when it became essential to peace, that all power should be centered in one man, these great intellects passed away. Then too the truthfulness of history was impaired in many ways; at first, through men's ignorance of public affairs, which were now wholly strange to them, then, through their passion for flattery, or, on the other hand, their hatred of their masters. And so between the enmity of the one and the servility of the other, neither had any regard for posterity. But while we instinctively shrink from a writer's adulation, we lend a ready ear to detraction and spite, because flattery involves the shameful imputation of servility, whereas malignity wears the false appearance of honesty]," Tacitus, Historiarum Libri, vol. 2, fasc. 1., in P. Cornelii Taciti libri qui supersunt, ed. Heinz Heubner (Stuttgart: Teubner, 1983), I.1; Tacitus, The Annals and the Histories, trans. Alfred John Church and William Jackson Brodribb (New York: Modern Library, 2003), 361. On Boccaccio's knowledge and use of Tacitus, see Zaccaria, Boccaccio narratore, storico, moralista e mitografo (Florence: L.S. Olschki, 2001), 197-213.

49. Although Boccaccio does not name them specifically, some relatively unknown Latin authors with whom he was familiar were Plautus, Tacitus, and Apuleius.

50. Boccaccio, Genealogie XV, 6, 12 (8:1536), trans. Osgood, Boccaccio, 116. Italics originate in Osgood. 
51. Boccaccio, Genealogie XV, 6, 12 (8:1538), trans. Osgood, Boccaccio, 117.

52. Boccaccio, Genealogie XV, 6, 13 (8:1538), trans. Osgood, Boccaccio, 117.

53. Petrarch, Familiares XXII, 2, 11-13 (64-69 and 72-80) in Le familiari, ed. Rossi and Bosco, 4:105-106; Petrarch, Letters on Familiar Matters, trans. Bernardo, 3:212-13, modified.

54. It is important to realize that Petrarch's representation of his memory of these authors does not reflect the reality of his engagement with them, but that it is a form of self-fashioning. For example, he owned a complete and highly annotated manuscript of Apuleius's works. On Petrarch's Apuleius manuscript, see Julia Haig Gaisser, The Fortunes of Apuleius and The Golden Ass: A Study in Transmission and Reception (Princeton: Princeton University Press, 2008), 77-82.

55. Boccaccio, Genealogie XV, 6, 1-2 (8:1528), trans. Osgood, Boccaccio, 111, modified. Italics added for emphasis.

56. Andalò del Negro (1260-c. 1344) was Boccaccio's teacher of astronomy and the author of two tractates that Boccaccio possessed: Sphere materialis and Theorica planetarum. Boccaccio refers to Andalò del Negro as an authority on astral phenomena eight times in the mythographical portion of the Genealogie. Boccaccio's use of del Negro's science is a central concern in Antonio Enzo Quaglio, Scienza e mito nel Boccaccio (Padua: Liviana, 1967). On del Negro, see the extensive note in Odonne Zenatti, ed., Dante e Firenze: Prose antiche (Florence: Sansoni, 1902), 268-69n1 and the more recent bibliography cited in Boccaccio, Genealogie, ed. Zaccaria, 8:1618n68.

57. Boccaccio, Genealogie XV, 6, 4 (8:1528-30), trans. Osgood, Boccaccio, 112, modified. This episode is also the basis for his 1370 tract De sui ipsius et multorum ignorantia.

58. Petrarch, Seniles V, 2, 34 (287-88), in Lettres, ed. Nota, 2:145; Petrarch, Letters of Old Age, trans. Bernardo, 1:164, modified.

59. Petrarch, Seniles V, 2, 36 (316-22), in Lettres, ed. Nota, 2:147; Petrarch, Letters of Old Age, trans. Bernardo, 1:165.

60. This was precisely what was happening in the intellectual milieu of late medieval science, especially in medicine. See Katharine Park's discussion of Florentine physician, Tommaso Del Garbo's innovations in medical theory and practice at the time, in Doctors and Medicine in Early Renaissance Florence (Princeton: Princeton University Press, 1985), 198-209.

61. Petrarch, Seniles V, 2, 23-25 (204-18), in Lettres, ed. Nota, 2:139-41; Petrarch, Letters of Old Age, trans. Bernardo, 1:162-63. 
62. Petrarch, Seniles V, 2, 31 (263-66), in Lettres, ed. Nota, 2:143, trans. Bernardo, 164, modified.

63. Petrarch, Seniles V, 2, 31 (266-67), in Lettres, ed. Nota, 2:143, trans. Bernardo, 164.

64. Petrarch, Seniles V, 2, 30 (256-58), in Lettres, ed. Nota, 2:143; Petrarch, Letters of Old Age, trans. Bernardo, 1:164.

65. Petrarch, Seniles V, 2, 30 (260-61), in Lettres, ed. Nota, 2:143; Petrarch, Letters of Old Age, trans. Bernardo, 1:164.

66. Boccaccio cites Dante four times in the mythographical portion of the treatisealong with three other times in Book XIV-and cites Francesco da Barberino only once. He has no real reason to defend his minimal reliance on them if not to posit them both as examples of the modern poetic renewal of antiquity in the vernacular. The same is the case for all of the modern authorities defended here, with the exception of the three Greek scholars and Theodontius, on whom he constantly relies for mythical material and interpretative authority.

67. Boccaccio, Genealogie XV, 6, 5 (8:1530), trans. Osgood, Boccaccio, 113.

68. Francesco da Barberino (1264-1348) was a notary and jurisconsult, but also, as Boccaccio mentions, a love poet, who wrote two didactic poems on the topic: the Documenti d'Amore and the Reggimento e costumi di Donna. Boccaccio cites him as an authority (along with Servius and Apuleius) at IX, 4, on the physical appearance of Cupid, son of Mars and Venus.

69. Boccaccio, Genealogie XV, 6, 6 (8:1532), trans. Osgood, Boccaccio, 113.

70. Boccaccio, Genealogie XV, 6, 5 (8:1530), trans. Osgood, Boccaccio, 113.

71. It is worth noting the similarity between da Barberino and the early Boccaccio: they both studied canon law, wrote love poetry, and were active citizens of Florence. It is possible that Boccaccio's defense of the older Florentine poetjurist was an oblique way of including himself in his vision of the present. Boccaccio never cites himself in the Genealogie. The closest he comes to doing so are his oblique mentions of the Buccolicum Carmen in XIV, 10 and XV, 13.

72. Cf. Houston, Building a Monument to Dante.

73. Petrarch's relationship, real and staged, with Dante and his works has constantly fascinated critics of both authors. The bibliography is immense, but it is the subject of a recent anthology of essays with a broad treatment and deep bibliography: Petrarch and Dante: Anti-Dantism, Metaphysics, Tradition, ed. Zygmunt G. Barański and Theodore J. Cachey Jr., The William and Katherine Devers Series in Dante Studies 10 (Notre Dame: University of Notre Dame Press, 2009). For an overview of the relationship between Dante and Petrarch that promotes 
the idea of Petrarch's anxiety about Dante as an author, Dante's importance for Petrarch's renewed interest in the Canzoniere after 1350, and an overall anti-dantismo in the Aretine poet, see Cachey's introductory essay, "Between Petrarch and Dante: Prolegomenon to a Critical Discourse," 3-49. More than an exponent of anti-dantismo tout court, however, Petrarch was concerned with a certain reception of Dante especially within the political sphere. See Barański, "Petrarch, Dante, Cavalcanti," 50-113 (75-82), where he writes that "it is less Dante and the Commedia that aggravate him than their reception" (79). Privately, indeed psychologically, Petrarch's engagement with Dante is much more complex, as this volume shows. Perhaps it would be better not to speak of an overall "positive" or "negative" reception of Dante on the part of Petrarch, but of a process of relocating Dante's spiritual journey within the space of the self. Petrarch engaged with Dante and the Commedia much in the same way that he engaged with the poets of antiquity, by competing with him on the plane of style (Familiares XXII, 2) and by gathering from his poetry, as a bee takes nectar from flowers to produce honey (Familiares XXIII, 19). In this regard Petrarch's competitive rewriting of Dante in the Rerum Vulgarium Fragmenta and the Trionf $\mathrm{might}$ be considered not so much against as in dialogue with Dante. See Mazzotta, "Petrarch's Dialogue with Dante," 177-94 and Christian Moevs, "Subjectivity and Conversion in Dante and Petrarch," 226-59. In large measure, this volume rightly responds to the problematic effort of other scholars to make Petrarch into an exemplar of dantismo. See, for example, "Dantismo Petrarchesco: Ancora su Fam. XXI 15 e dintorni," in Motivi e forme, 21-38; but see also Marco Santagata's prudent words on the question in his Introduzione to Petrarch, Canzoniere, edizione aggiornata (Milan: Mondadori, 2004), XIX-CII.

74. Petrarch, Familiares XXI, 15, 22 (175-79), in Le familiari, ed. Rossi and Bosco, 4:99; Petrarch, Letters on Familiar Matters, trans. Bernardo, 3:205-206.

75. On the three redactions of the Vita Dantis, see Pier Giorgio Ricci, Introduzione, in Boccaccio, Vite di Dante $\mathrm{v}-\mathrm{xv}$. On the first redaction's implicit Petrarchization of Dante, see Todd Boli, "Boccaccio's Trattatello in laude di Dante, or Dante Resartus," Renaissance Quarterly 41, no. 3 (Autumn 1988): 389-412. On the Dante/Petrarch question in Boccaccio's cultural program, see Houston, Building a Monument to Dante, esp. 64-73, 93-98, and 124-56; and Warren Ginsberg, Chaucer's Italian Tradition (Ann Arbor: University of Michigan Press, 2002), esp. 105-47 and 190-39. On the sources of Boccaccio's depiction of Dante, see Karen Elizabeth Gross, "Scholar Saints and Boccaccio's Trattatello in laude di Dante," MLN 124, no. 1 Italian Issue (January 2009): 66-85.

76. The contrast between the two scholars over the role of the vernacular can also be seen in the four letters of Book Seventeen of the Seniles, in which Petrarch futilely seeks to stabilize and rectify the ambiguity of Boccaccio's novella of Walter and Griselda (Decameron X.10) by translating it into Latin. On the questions of translation that this novella evokes, see David Wallace, The Chaucerian Polity, 277-93 and more recently his essay "Letters of Old Age: 
Love between Men, Griselda, and Farewell to Letters (Rerum senilium libri)," in Petrarch, ed. Kirkham and Maggi, 321-32.

77. It is clear from Petrarch's obsession with the Rerum Vulgarium Fragmenta and with his continuous development of the Trionfi, which lasted up until his final breath, that there is an inherent divide between Petrarch's public portrayal of himself as a Latin writer and his dedication to the private self in his vernacular work. Nevertheless, even in the 1373 letter to Pandolfo Malatesta that accompanied a late redaction of the Fragmenta, Petrarch expresses his disappointment with the work's popularity. He is concerned that it will detract from his authority: "stilo quolibet ingenium illius etatis emineat: ipse tamen res senilem dedecet gravitatem [For while the talent of that age may emerge in any style whatsoever, still the subject matter does not become the gravity (gravitas) of old age]," Petrarch, Seniles XIII, 11, in Lettres, ed. Nota, 4:177; Petrarch, Letters on Old Age, trans. Bernardo, 2:500. Quite plainly, the vernacular style is excusable because of youth, but the subject detracts from the authority he had acquired in old age. Petrarch's critique of himself also inverts the terms of his dismissal of Dante in Familiares XXI, 15. Cf. Aldo S. Bernardo, Petrarch, Laura, and the Triumphs (Albany: State University of New York Press, 1974), 51. On Petrarch's conception and representation of himself as a vernacular author, see Santagata, I frammenti dell'anima: Storia e racconto nel Canzoniere di Petrarca (Bologna: Il Mulino, 1992) and Ascoli, "Favola fui": Petrarch Writes his Readers, Bernardo Lecture Series 17 (Binghamton: CEMERS, 2010). On the division of the public and private self in Petrarch's works, see Reiss, Mirages of the Selfe, 303-52.

78. The irony of history is that Petrarch's vernacular poetry is precisely what assured the endurance of his fame.

79. Barlaam of Seminara (c. 1290-1348) was a Basilian monk and theologian well known for his role in the Heyschast controversy, during which he accused Gregory Palamas of heresy. Although he lost his case against Palamas after two patriarchal synods in 1341, he was supported throughout by Byzantine Emperor Andronicus III. Earlier in his career he had been the imperial emissary to the papacy, Robert of Naples, and Phillip VI in Paris, to discuss the union of the churches and had met Petrarch in 1339 in Avignon. After Barlaam's defeat in 1341 and the death of Andronicus that same year, he returned to Avignon in 1342, where, largely due to Petrarch's intercession, he was made Bishop of Gerace, where he died in 1348 of the plague. Boccaccio cites him as an authority on Greek myth more than twenty times in the mythographical portion of the treatise. See Zenatti, Dante e Firenze, 273-74n3 and Boccaccio, Genealogie, ed. Zaccaria, 8:1612n5.

80. Boccaccio, Genealogie XV, 6, 7 (8:1532), trans. Osgood, Boccaccio, 113.

81. Paolo da Perugia (d. 1348) was a notary and the librarian of Robert of Naples's court, whose Collectiones were a major source for Boccaccio in the Genealogie. On what remains of his work, see Hankey, "Un nuovo codice," in addition to 
Hortis, Studj, 494-98 and 525-36. Boccaccio mentions Paolo more than seventy times in the mythographical portion of the treatise, not counting the over two hundred times that he invokes Theodontius.

82. Boccaccio, GenealogieXV, 6, 8 (8:1532-34), trans. Osgood, Boccaccio, 114, modified.

83. Leontius Pilatus (d. 1366) was born in Calabria and was likely a student of Barlaam in Gerace. Pertusi speculates that he must have left Gerace for Crete in 1346, while Barlaam was on a mission to Constantinople for Clement VI. In 1358-59, however, he was in Padua, where he met Petrarch. He spent almost three years in Florence (Spring 1360-Fall 1362) as a guest of Boccaccio, where he lectured on and translated Homer, after which time he went to Venice, where he remained as Petrarch's guest until the fall of 1363, when he departed definitively for Greece. In Seniles VI, 1, Petrarch records Leontius's death by lightning as he tried to make his way back to Italy from Greece in 1365. See Pertusi, Leonzio Pilato, 1-42. For other discussions of Leontius in Florence, see notes four and five above. Boccaccio cites Leontius more than seventy times in the first thirteen books of the Genealogie.

84. Boccaccio, Genealogie XV, 6, 9 (8:1534), trans. Osgood, Boccaccio, 114, modified.

85. Petrarch himself notes that he was unable to learn Greek from Barlaam in 1339, whose poor Latin was nonetheless better than Petrarch's Greek, and that he abandoned the study of Greek in his youth after the death of the Greek monk. See Petrarch's 1354 letter to Nicola Sigero, Familiares XVIII, 2. Cf. Weiss, "Petrarca e il mondo greco," 179, and Hankins, "Greek Studies in Italy," 330-31.

86. See Petrarch, Familiares XXIV, 12, in Le familiari, ed. Rossi and Bosco, 4:253-63, trans. Bernardo, Letters on Familiar Matters, 3:342-50. The letter is a prose "responsio ad epystolam magnam multaque continentem sub Homeri poete missam nomine et apud Inferos datam [reply to a lengthy and highly informative letter addressed to him in the name of the poet Homer from the realm of the dead]," in which Petrarch stages his own mediated relationship to the Greek poet both in the letter's addressee and in its prose form. Unlike the letter to Virgil, which Petrarch evokes in contrast, the letter is written in prose, since he knows the Greek poems only in translation. He highlights Homer's distance from himself by defending Virgil's unacknowleged imitation. Homer is represented in this letter as irredemably mediated: both by the poetry of Virgil, who bettered him, and by the prose translation, which destroys Homer's poetry. It becomes clear from the letter that the Roman poet, who in Petrarch's eyes had overcome his Greek predecessor, is the true model for Petrarch. If there is a Homeric legacy, then it is accessible to Petrarch only in the direct engagement with Virgil, not in the unmediated reappropriation of Homer that Boccaccio advocated. Petrarch was indeed enagaged in the translation of Homer's poems, but he insisted on a verbum pro verbo translation to be transcribed and read in Latin alone. If not completely opposed to learning Greek, he dismissed it 
entirely by attributing his lack of Greek letters to the misfortune of youth. See Epistola Dispersa 46, in Petrarch, Lettere disperse: varie e miscellanee, ed. Alessandro Pancheri (Parma: Fondazione Pietro Bembo, 1994), 338-58 (esp. 352). See also Pertusi, Leonzio Pilato, 22 and 73-111, where he claims that the addressee of the letter to the pseudo-Homer is actually Boccaccio.

87. Boccaccio, GenealogieXV, 7, 5-6 (8:1540), trans. Osgood, Boccaccio, 120, modified.

88. As I will discuss below, Petrarch desired a Latin translation of Homer for entirely different reasons than Boccaccio. His manuscripts of Homer's two poems contained only the Latin translation, whereas Boccaccio worked from an interlinear translation. On Petrarch's central role in introducing Boccaccio to Leontius and in helping them procure Greek manuscripts, see Pertusi, Leonzio Pilato, 1-42.

89. Boccaccio, GenealogieXV, 6, 9 (8:1534), trans. Osgood, Boccaccio, 114, modified.

90. Boccaccio, GenealogieXV, 6, 9 (8:1534), trans. Osgood, Boccaccio, 114-15, modified.

91. It is worth noting in this regard that Boccaccio's defense of Greek poetry in Chapter Seven responds to those who accuse him of ostentation in quoting Greek: "Seu hos, seu alios dicituros non dubito quoniam ostentationis gratia greca carmina operi meo inseruerim [It is safe to say that these critics and others will charge me with purely gratuitous and ostentatious quoting from Greek poetry]," Boccaccio, Genealogie XV, 7, 1 (8:1540), trans. Osgood, Boccaccio, 118.

92. Petrarch, Seniles V, 3, 9 (82-84), in Lettres, ed. Nota, 2:153; Petrarch, Letters of Old Age, trans. Bernardo, 1:169.

93. See Petrarch, Seniles V, 3, 21 (193-200), in Lettres, ed. Nota, 2:161; Petrarch, Letters of Old Age, trans. Bernardo, 1:172.

94. Petrarch, Seniles V, 3, 29 (262-66), in Lettres, ed. Nota, 2:165; Petrarch, Letters of Old Age, trans. Bernardo, 1:173.

95. Petrarch, Seniles V, 3, in Lettres, ed. Nota, 2:171; Petrarch, Letters of Old Age, trans. Bernardo, 1:176. Taken together with the aforementioned 1370 letter to Giovanni Dondi da Padova (Seniles XII, 2), this letter unveils one of Petrarch's major misgivings about the Greek tradition. That is, because it had been transmitted historically through Latin translations of Arabic commentaries, Greek and Arabic culture were inextricable from one another. By focusing on a Roman reception of the Greeks, via competition with them, Petrarch reestablishes a cultural autonomy for the Italic peninsula founded upon the convergence of Christian and Roman values.

96. Petrarch, Seniles V, 3, title, in Lettres, ed. Nota, 2:149; Petrarch, Letters of Old Age, trans. Bernardo, 1:167. 
97. In fact, suggesting that the real subject of the letter is Pilatus, at the end of the invective against the physicians Petrarch notes: "Sed iam satis lusimus: de medicis quidem nostris et multa olim ex professo et hec hodie incidenter dixerim [But we have joked enough; in the past I have seriously said much about our doctors; take what I have said today as incidental]," Petrarch, Seniles V, 3, 38 (359-61), in Lettres, ed. Nota, 2:171; Petrarch, Letters of Old Age, trans. Bernardo, 1:176.

98. Petrarch, Seniles V, 3, 39-40 (366-70 and 373-79), in Lettres, ed. Nota, 2:173; Petrarch, Letters of Old Age, trans. Bernardo, 1:176, modified. There is not a little irony in Petrarch's ire at Leontius for having abandoned Florence, since Petrarch himself refused to return there in 1351 and instead took up residence in Milan in 1353. Petrarch could choose between two Italian cities, but it was anathema to abandon an Italian city for Greece.

99. In another letter to Boccaccio from earlier in 1365 (Seniles III, 6), impatient to receive Leontius's Latin prose translation of the Odyssey from Boccaccio, Petrarch had noted Leontius's bad manners and odd behavior during his sojourn with him in Venice. He connects Leontius's bad manners to his rejection of Italy and Latin, but he criticizes above all the Calabrian's instability. Althougth Leontius had cursed Italy upon leaving Venice, he writes to Petrarch from Constantinople that he hates Greece, misses Italy, and that he would like Petrarch to invite him back. Petrarch never responds to Leontius, and the narration of these events of 1363 becomes the pretense in 1365 for a critique of the Greek culture in a comparison with the Romans: "Greci enim Constantinopolim alteram Romam vocant, quam non parem modo antiquique sed maiorem corporibus ac divitiis effectam dicere ausi sunt; quod si in utroque verum esset, sicut in utroque . . f falsum est, certe viris armis ac virtutibus et gloria parem dicere, quamvis impudens, greculus non audebit [For the Greeks call Constantinople another Rome. They have dared to call it not only equal to the ancient city, but greater in monuments and graced with riches. But if this were as true on both counts as it is false . . surely no little Greek, however impudent, would dare to call them equal in men, arms, virtues, and glory]," Petrarch, Seniles III, 6, in Lettres, ed. Nota, 1:259; Petrarch, Letters of Old Age, trans. Bernardo, 1:101. It is important to note that Petrarch changes his tone when he learns of Leontius's death at sea by lightning in the summer of 1365. He records in a 1366 letter to Boccaccio (Seniles VI, 1) that Leontius was returning to Italy from Byzantium to take up residence with Petrarch himself, because he had realized the error of preferring Greece to Italy. Whereas Petrarch had wished Leontius to be food for Greek worms only a few months earlier, in this letter he notes that in the end Leontius had become food for Italian fish. It seems that Petrarch's distaste for Leontius is to be connected somehow to the issue of the schism between the Greek and Latin Churches. Barlaam had been involved in negotiations for a reconciliation and had chosen the Latin Church over Byzantium in the end, whereas Leontius had been unable to make a decision. Leontius's conversion in extremis to Latinity-understood both as the Roman Church and the Italic culture-is recorded by the fate of his body. 
100. Petrarch, Seniles V, 1, 15 (142-59), in Lettres, ed. Nota, 2:125; Petrarch, Letters of Old Age, trans. Bernardo, 1:155-56.

101. One other important question here regards how Petrarch stages the roles that each plays in their intellectual friendship. Boccaccio is portrayed as a scribe and cultural mediator of the third degree, who transcribes the Latin translations of Leontius Pilatus, which Petrarch will then activate creatively in his work. Petrarch, who promises to have someone else transcribe the Greek codex, portrays himself as the real cultural actor, in that he is the origin of the material knowledge of the Greek world, possessing the codices on which others depend. Petrarch negotiates their relationship so that the inferior manual labor of the translator and scribe is juxtaposed to that of the collector and poet. In the lines that follow the cited passage, Petrarch makes it clear that the effort of having Homer translated and transcribed in Latin belongs to Boccaccio, and that his own job is to pay for the work: "in futurum autem, si me amas, vide, obsecro, an tuo studio, mea impensa fieri possit ut Homerus integer bibliothece huic, ubi pridem grecus habitat, tandem latinus accedat [In the future, however, if you love me, I beg you: see whether it can be arranged through your effort, at my expense, that all of Homer in Latin may enter this library where he has long dwelt in Greek]," ibid. By asserting the centrality of his own role in bringing Greek back to Tuscany in Chapter Seven of the Genealogie, Boccaccio is responding to Petrarch's assertion here.

102. See Leonzio Pilato, 28n2. Pertusi has interpreted Boccaccio's mistake as a simple misunderstanding, but I am more suspicious of Boccaccio's motivations.

103. That Petrarch's understanding of the Homer/Virgil imitative nexus culminates not only in Petrarch's attitude toward imitating Virgil, but also his authorial stance vis-à-vis Dante, is perhaps implied by Ascoli's reading of allusions to Dante in Petrarch's first eclogue Parthenias. See Ascoli, "Blinding the Cyclops: Petrarch after Dante," in Petrarch and Dante, ed. Barański and Cachey, 11473 (esp. 124-37). See also Santagata, Introduzione XLIX, where he equates Petrarch's mode of imitation in Latin to that in the vernacular, and McLaughlin, Literary Imitation, 34-48.

104. According to Pierre de Nolhac, Petrarch would have wanted the sections of Homer's descriptions of Italy in order to include them in the De vita solitaria, which he announces to have concluded in this very letter. See de Nolhac, Pétrarque et l'humanisme, 2 vols. (Paris: H. Champion, 1907), 2:163. The section of the De vita solitaria that addresses poetic solitude begins with Homer, who is followed by Virgil and Horace. See De vita solitaria XII, 2, 6-10. On this question, see Pertusi, Leonzio Pilato, 27-28.

105. On Petrarch's self-identification with Odysseus, or rather Dante's Ulysses, see Enrico Fenzi, "Tra Dante e Petrarca: Il fantasma di Ulisse," in Saggi petrarcheschi (Florence: Cadmo, 2003), 492-517, whose reading is put into question by Cachey in "Between Dante and Petrarch," in Petrarch and Dante, ed. 
Barański and Cachey, 35-39. See also Mazzotta, "Petrarch's Epistolary Epic: Letters on Familiar Matters (Rerum Familiarum Libri)," in Petrarch, ed. Kirkham and Maggi, 309-19.

106. The greater part of this letter praises the history of Pavia and the marvels of the modern Viscontian architecture. Petrarch tells Boccaccio that he wishes the Certaldan had visited on his way to and from Avignon because, alluding to Boccaccio's admiration of novelty and art, he thinks that Boccaccio would have appreciated the city. He also mentions the tombs of Boethius and Augustine and other examples of the city's antiquity, which meld with and add dignity to the new architecture. The Visconti regime, then, heroically enacts Petrarch's own novel antiquity, and Petrarch tries, somewhat ironically, to seduce Boccaccio to his point of view-both politically and intellectually. The description of Pavia and the coda on Homer speak to the same concern of modernity's relationship to antiquity within a political context.

107. Paolo Geometra (1281-1367) was also known as Paolo di ser Pietro Dragomari or Paolo Geometra de l'Abbaco. As Quaglio notes in Scienza e mito 40n22, Paolo was the author of Il Trattato d'Abbaco di Astronomia e di Segreti Naturali e Medicinali, written around 1339. See also Zenatti, Dante e Firenze, 280n1.

108. Boccaccio, GenealogieXV, 6, 10 (8:1534), trans. Osgood, Boccaccio, 115, modified.

109. Here, Petrarch mentions specifically the recent death of Lelius (Angelo di Pietro Stefano dei Tosetti) and Simonides (Francesco Nelli), as well as the previous passing of Socrates (Ludwig von Kempen).

110. Petrarch, Seniles III, 1, 50 (384-90), in Lettres, ed. Nota, 1:227, trans. Bernardo, $1: 85$, modified.

111. Petrarch, Seniles III, 1, 51 (390-92), in Lettres, ed. Nota, 1:227, trans Bernardo, 1:85.

112. Petrarch, Seniles III, 1, 52 (400-06), in Lettres, ed. Nota, 1:227-28, trans. Bernardo, 1:85.

113. The history of poetry that Boccaccio traces in the Genealogie begins with human marvel before the productive powers of nature. In his defition of poetry in Book Fourteen of the treatise, he notes that poetry itself, described as mirabilis, is capable of reproducing aesthetically the original marvel of nature with sublime effects. See Boccaccio, Genealogie XIV, 7. To compose poetry properly, Boccaccio notes, it is necessary to know the "et liberalium aliarum artium et moralium atque naturalium ... principia [the principles of the other liberal arts, both moral and natural]," Boccaccio, Genealogie XIV, 7, 3 (8:1401), trans. Osgood, Boccaccio, 40. Cf. Lummus, "Boccaccio’s Poetic Anthropology."

114. Petrarch, Seniles III, 1, 36 (277-79), in Lettres, ed. Nota, 1:219-20, trans. Bernardo, 1:82, modified. 
115. Boccaccio, Genealogie XV, 6, 10 (8:1534), trans. Osgood, Boccaccio, 115.

116. Boccaccio, Genealogie XV, 6, 11 (8:1536), trans. Osgood, Boccaccio, 115-16, modified.

117. On Petrarch's friendships with Greeks and others connected to Byzantium, see Pertusi, Leonzio Pilato, 1-42. For his correspondence with Nicola Sigero, ambassador of the Byzantine emperor John VI Kantakouzenos and the donor of Petrarch's Greek codex of the Iliad, see ibid., 43-53.

118. For Paolo Geometra as "concivum meum" (my fellow townsman), see Genealogie XV, 6, 10 (8:1534), trans. Osgood, Boccaccio, 115. For Petrarch as "florentinum" (of Florence), see Genealogie XV, 6, 11 (8:1536), trans. Osgood, Boccaccio, 115.

119. From the time he first met Petrarch in Florence in 1350, Boccaccio wanted to make a place for him there in the city. In 1351, he convinced the Florentine government to restore some of Petrarch's family's ancestral lands to him and to support him as a professor at the Studium. See his official epistle to Petrarch on behalf of Florence, Epistola VII, in Boccaccio, Epistole, 550-57. This first effort was thwarted by Petrarch's self-imposed exile, which expressed itself as a disdain for associative forms of government and ended in Petrarch's election to reside among the Visconti in Milan. The political break that took place between Petrarch and Boccaccio in 1353 marked their friendship for the rest of their lives. For Boccaccio's biting critique of Petrarchan subjectivity on this occasion, see his Epistola X, in Boccaccio, Epistole, 574-83. In a certain sense, Petrarch forever remained for Boccaccio the Roman poet of the Africa, Collatio laureationis, and Buccolicum Carmen. In 1374, after Petrarch had died, Boccaccio addressed a carmen (IX) to the Africa itself, beseeching it to return to Florence, its mother, under whose protection it would be able to offer itself to future generations. See Carmina, ed. Giuseppe Velli, in Boccaccio, Tutte le opere, vol. 5, part 1, 375-492 (442-52), esp. 446-48 (lns. 85-102 and 125-28). See also Boccaccio's 1374 letter to Petrarch's son-in-law Francesco da Brossano, in which he expresses his sadness for Petrarch's death and his concern for the fate of the Africa, Trionfi, and Petrarch's library, in Boccaccio, Epistole, ed. Auzzas, 726-36.

120. If we consider the addressees of the Familiares as making up Petrarch's exclusive circle of friends, then, as is well known, by including the veteres illustres or antiqui illustriores in Book XXIV (Cicero, Seneca, Varro, Quintilian, Livy, Pollio, Horace, Virgil, and pseudo-Homer), Petrarch creates an ancient canon that rotates around his own personal memory and imaginative reworking of history.

121. Boccaccio Genealogie XV, 6, 11 (8:1536), trans. Osgood, Boccaccio, 115, modified.

122. On the Collatio Laureationis see Janet Levarie Smarr, "Petrarch: A Virgil without a Rome," in Rome in the Renaissance, ed. P. A. Ramsey (Binghamton: CEMERS, 1982), 133-40; Mazzotta, "Petrarca e il discorso di Roma," in Petrarca. Canoni, esemplarità, ed. Valeria Finucci (Rome: Bulzoni, 2006), 259-72; and Dennis Looney, "The Beginnings of Humanistic Oratory: Petrarch's Coration Oration 
(Collatio laureationis)," in Petrarch, ed. Kirkham and Maggi, 131-40. On the differences between the Collatio laureationis and the much more widely circulated document of the Priviegium laureationis, which legally records the awarding of the the laurel crown, see Jonathan Usher, "Petrarch's Diploma of Crowning: The Privilegium laureationis," in Italy and the Classical Tradition: Language, Thought, and Poetry 1300-1600, ed. Carlo Caruso and Andrew Laird (London: Duckworth, 2009), 161-92. For the text of the Privilegium, see Dieter Martens, "Petrarcas 'Privilegium laureationis,"” in Litterae Medii Aevi: Festschrift für Johanne Autenrieth zu ihrem 65. Geburtstag, ed. Michael Borgolte and Herrad Spilling (Sigmaringen: Thorbecke, 1988), 225-47. On the laurel crown as a connection between Dante and Petrarch, especially for Boccaccio, see Sara Sturm-Maddox, "Dante, Petrarch, and the Laurel Crown," in Petrarch and Dante, ed. Barański and Cachey, 290-319.

123. Petrarch, Scritti inediti di Francesco Petrarca, ed. Attilio Hortis (Trieste: Tipografia del Lloyd Austro-Ungarico, 1874), 311-28 (317-18), trans. Ernest H. Wilkins, "Petrarch's Coronation Oration" PMLA 68, no. 5 (Dec. 1953): 1241-50 (1245), modified. A more recent edition of the Collatio, which includes readings from a newly discovered manuscript, is available in Carlo Godi, "La 'Collatio laureationis' del Petrarca nelle due redazioni," Studi Petrarcheschi 5 (1988): 1-56. With the reading of this particular passage the same in both redactions, I have used the Hortis edition, since it is more readily available and it is the reference text for the English translation by Wilkins.

124. That competition with the poets of the past was at the heart of Petrarch's desire to be crowned poet laureate in Rome, see his letter to King Robert of Naples, Familiares IV, 7, in Le familari, ed. Bosco and Rossi, 1:171-74; Petrarch, Letters on Familiar Matters, trans. Bernardo, 1:193-95.

125. The ironic gap between the "honor of the Republic" and the present state of affairs in Petrarch's Rome is manifest in Petrarch's letter to Barbato da Sulmona, King Robert of Naples' royal secretary, in which he describes his departure from Rome after the ceremony: "vix menia Urbis egressi, ego cum his qui me terra et pelago secuti errant, in latronum armatas manus incidimus; e quibus ut liberati et Romam redire compulsi fuimus, quantusque ibi ob hanc causam populi motus, et ut die postero certiori armatorum fulti praesidio descessimus, ac caeteros viae casus si explicare tentavero, longa erit historia [we had scarcely left the walls of the city when I, together with those who had followed me on land and sea, fell into the hands of an armed band of thieves. How we were freed from them and were forced to return to Rome, how upset the people were because of this, how we left on the following day supported by an escort of armed men, and the other events of our trip would make too long a story for me to attempt to relate here]," Petrarch, Familiares IV, 8, 3 (17-22), in Le familiari, ed. Rossi and Bosco, 1:175; Petrarch, Letters on Familiar Matters, trans. Bernardo, 1:196. The phantasm of ancient Rome that Petrarch appropriates in his memory and elaborates in his works, disappears in reality, as it resides only within the rhetorical economy of the oration. The realities of history, to which 
Petrarch is exiled, are held at bay by his efforts at cultural renewal, which history both defines and threatens to destroy.

126. That Boccaccio's inclusive vision of the studia humanitatis in the Genealogie presaged future humanism becomes clear in the years following the Council of Florence in 1438, and especially in the humanist culture of thinkers such as Ambrogio Traversari and the scientific culture of physicians like Paolo Toscanelli, and later on in the totalizing humanist vision of thinkers such as Angelo Poliziano. On the convergence of scientific and humanistic culture in mid-Quattrocento Florence, see Park, Doctors and Medicine in Early Renaissance Florence, 220-36. According to Park, it was the study of Greek that allowed for a rapprochement of medicine and humanism. For a broad introductory summary of Renaissance Hellenism that begins with Petrarch and ends with Guillaume Budé, strangely skipping Boccaccio, see Christopher S. Celenza, "Hellenism in the Renaissance," in The Oxford Handbook of Hellenic Studies, ed. G. R. Boys-Stones, Barbara Graziosi, and Phiroze Vasunia (Oxford: Oxford University Press, 2009), 150-65. 